\title{
ヒトおよび諸種峬乳動物唾液腺の組織学的, 組織化学的ならびに電子顕微鏡的研究
}

V. ハムスタ一耳下腺の電子顕微鏡的研究

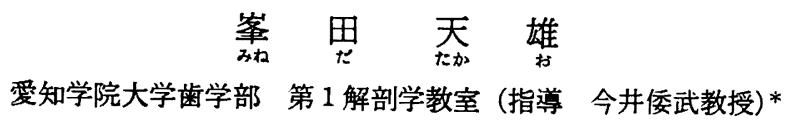

[受付 : 昭和46年11月 9 日]

緒言

唾液腺の形態学的研究は光学顕微鏡的, 電子顕 微鏡的および組織化学的に多くの研究がなされて いる。電子顕微鏡的研究としてはラッ.. ${ }^{1-23)}$ ，マウ

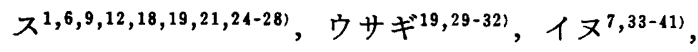
ネコ19,42-45)，ヒト 16-58)などがおもな研究対象とさ れ，その他ウシ ${ }^{19,21,59,60) ， ヒ ッ シ ゙ 19,21,61,62) ， 才 ホ ゚ ~}$ ッサム $18,19,63)$ 等がある。

ハムスターについては SHACKLEFORD・WILBORN ${ }^{18)}$ が簡単な記載をしているのみで，詳細な 研究はほかにはない。それゆえその構造の詳細を 明らかにするとともに，細胞の機能すなわち終末 部，陕部および線条部におけるそれぞれの細胞の 分泌物の生産, 排出などについて形態学的に観察 した。

\section{材料および方法}

材料には飽食状態のハムスター (golden hamster)雄成体（体重 120 130 g) 7 匹を使用しクロロ ホルム麻酔を行ない, 直ちに臟器を剔出して, Millonig のオスミウム酸固定液に入れ, $4^{\circ} \mathrm{C}$ 冷蔵 庫中で Penetron II 型(三慶科学研究所製)で回転さ せながら 2 時間固定した。エタノール脱水後 $\mathrm{QY}_{1}$

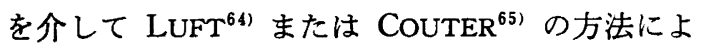
りエポン包埋した。ブロックは Porter-Blum I 型 ultramicrotome で薄切し, OHKURA・TAKASHIO ${ }^{66)}$ による酢酸ウラニウム染色と，VENABLE·COGGESHALL $^{67)}$ による鉛染色との二重染色を行ない， $\mathrm{JEM} \mathrm{T}_{2}$ 型電子顕微鏡で検鏡, 撮影した。一方, 対照の光学顕微鏡用切片をつくり, 山元 ${ }^{68)}$ にるる toluidin blue 染色および PAS 染色を行ない検鏡 した。

\section{所見}

\section{I 光顯的所見}

他の諸種ホニュウ動物の耳下腺と同様にハムス ター耳下腺では終末部, 峡部, 線条部, 導管の各 部が区別される。この動物の特徵として, 峡部細 胞が他の動物のものより大きく，細胞の分泌機能 が旺盛で, 終末部との接触部では終末細胞間に介 在して腺腔を囲む像もみられ，一見して 2 種の細 胞からなるイエウサギ顎下腺を思わせる。

エポン切片の PAS 染色では終末細胞の細胞質 が弱陽性を示し, 分泌顆粒の周辺部は比較的強い 陽性を示し，さらに内部は弱陽性であるが，その 陽性度は細胞質より弱い。顆粒のうちには周辺部 が強い PAS 陽性を呈する半月または三日月状を 呈するものおよび顆粒中心部が強く，その周辺が 弱い反応を呈するものがある。

峡部細胞は分泌顆粒が強陽性に染まり， 終末細 胞のそれらより一般に反灾が強い。なお本細胞に

Histological, histochemical and electron microscopic studies on the salivary glands in man and many kinds of animals. V. Electron microscopic investigations on the parotid gland in the hamster

T. MiNedA (Department of Anatomy, School of Dentistry, Aichi-Gakuin University, Nagoya)

* 名古屋市千種区未盛通り 2 の11（テ464）

Jap. J. Oral Biol. 14(1) : 59-100, 1972. 
現われる crystalloid も顆粒と同様に強い陽性を呈 する。

線条部は反応が陰性である。

toluidin blue 染色でも 終末細胞, 峡部細胞は PAS 染色と同様の反応を示す。

線条部は境界膜と核だけが 淡く染まる程度であ る。

\section{II 電顕的所見}

\section{A 終末部細胞}

終末部には 3 種の細胞が区別される。一つは腺 細胞(終末細胞)で終末部のほとんどを占める。他 の一つは終末部基底明調細胞と考えられるもの で, 終末部の基底に位置し細胞体は明るい。この ような細胞は峡部細胞の基底にも一部みられた。 残りの一つは筋上皮細胞(籠細胞)である。なおこ の種のものは峡部ではより多く存在して, 管を取 り巻くような状態で配列しているが，その詳細に ついてはCで述心゙る。

\section{1. 終末細胞(腺細胞)}

終末細胞の形態はピラミッド状を呈し，大きさ は長径平均 $15.5 \mu$ 程度である。核は細胞中央部よ り基底に偏在し，楕円形で，その長径は細胞の長 軸に対して直角である。核の輪郭は凹凸を示す (図 1)。核膜には一切片で十数個の膜孔がみられ る。核膜内膜には電子密度の高い異質染色質 ( テロクロマチン）が集積し密着しているが，膜孔 部にはこのようなものは認めれない。核中心部は 比較的明るい真正染色質によって形成せられ，こ の間に異質染色質の島状をなすものおよび interchromatin granule の集合体が散在しているのが みられる。核小体はときどき認められるが，その 電子密度は細胞により異なる。

さらに核内構造物として, WEBER·FROMMES $(1963)^{69)}$ が報告した nuclear body は 1 個の核内 に 1 個とは限らず, $1 \sim 3$ 個を有するものがあ る。大きさは $0.35 \mu$ 程度の小さいものから $1.00 \mu$ 以上のものまでがみられる。それらの形態は大き く分けて 3 種の型に分類される。Type I は真正 染色質より電子密度の低い細線維または構造のは っきりしない物質が 球状を呈する型である（図 3 )。Type IIは細線維が環状をなして中央に空所
を有する型である(図 4)。Type III 中央に異質染色質よりも電子密度の高いオスミウ 厶酸好性顆粒を有するものである（図 5 )。Type I に属するものは $0.40 \mu$ 前後の大きさで最も小 さい形態であり，出現頻度が最も高い。もしこの ようなものが 1 個の核に $1 \sim 3$ 個存在する場合に は，それらがすべて Type I または Type IIだけ のこともあり，さらに 3 種のものが混在すること もある。Type II といっても種々の形態が認めら れる。たとえば個々の細線維を識別することはで きないが，おそらくはその幾本かの集まったもの が環状をなすもの，1本の細線維が数回環状に取 り巻くのが明らかなもの, 取り巻いた細線の一端 が中央に出て，さらにコイル状をなし，それが環 状を呈するものなどがそれである(図 6 )。一方大 きさにも変異があり， Type Iよりわずかに大き いものから $1.00 \mu$ 以上のものまでがみられる。 Type IIの出現頻度は Type I の約半分ぐらいで あるが，Type III が十数例しかみられなかったの に比べれば高い。Type III の中央部にみられる顆 粒は，大きいものはグリコーゲン顆粒と同じ程度 のものから, interchromatin granule または異質 染色質を構成する粒子と同じ程度のものまでがみ られる。

その他の核内封入体として lipid を有するもの. が 1 例だけ認められた。

細胞質では粗面小胞体がよく発達し，細胞周辺 部には層板状に 輁状のものが配列 し, 細胞中心 部，すなわち核上部から腺腔側にはゴルジ装置， 多くの分泌顆粒が散在する。それらの間には少量 の震状をなすもの，あるいは管状または液胞状の 粗面小胞体が介在する。そのほか遊離のリボゾー ムおよびポリゾームも認められる。

系粒体には楕円形ないしは円形を呈するものが. 多く, cristae はよく発達しおり, 細胞質全体に散 在する。手粒体基質は比較的明るく, dense mitochondrial granule は認められない。

ゴルジ装置はよく発達し，核上部に数個みら れ，しばしばゴルジ野をなすのがみられる。ゴル ジ蓑は 3 ないし 4 層をなし，長く伸びて弧を描. く。ゴルジ野を呈するものでは一般にゴルジ装置 
の外方(凸側, forming immature face) に空胞が みられるが, その空胞同志が疹合して亜鈴型を示 すと思われる形態が認められる。ゴルジ軎は内方 (凹側, mature face) のものほど扁平である。空 胞のさらに外方には粗面小胞体があるが，それら が空胞状を呈する場合がしばしば認められる。そ れらのうちにはゴルジ装置に面する側にリボゾー ムを有しないもの，あるいはリボゾームを全くも たない空胞が混在するのがみられるが，これは上 記の粗面小胞体が リボゾームを失ったものと考え られ，直接ゴルジ空胞に移行するように見受けら れる。これらの空胞状小胞体の外方には層板構造 をなす輁状の粗面小胞体が存在する。一方, ゴル ジ装置内方には電子密度のやや高いゴルジ小胞が 多数みられ，分泌顆粒のまわりに集まっている像 も認められた。またそれらがゴルジ囊の端に集ま り，ゴルジ踤に融合し，またはゴルジ囊から分離 するかに見える像も認められ，さらにゴルジ装置 外方の空胞の間に少数見られる場合がある。一般 にいわれているようにゴルジ装置と分泌顆粒との 関係が認められる。ゴルジ囊の内方の一端がふく れているもの，ゴルジ囊が分泌顆粒を包むかのよ うに取り巻き顆粒を中心にして同心円状の配列を するもの等がみられるが，これらはゴルジ装置に おける分泌顆粒形成の過程を思わせる。

分泌顆粒の形態(図 1，2)は種々であるが, 大 多数のものでは内容は電子密度が低く細く短い線 維状の物質と, これより電子密度の高い粒状物質 との 2 成分からなる。粒状物と線維状物とはそれ ぞれ顆粒の一部に集積する傾向がみられるが, 両 物質の少ない顆粒では，両物質が顆粒内全体に散 在し, 顆粒は最も明るい。次いで上記 2 成分を多く 有する顆粒で粒状物の集まる量によって 顆粒内に 比較的電子密度の高い部分と低い部分とが現われ ることがある。また線維状物むその集まる状態に よって粒状物の場合と同じょうな形態を示すこと がある。さらにそれらの電子密度の高、部分に, それより一層電子密度の高、塊状物を含むものが ある。この塊状物は輪郭がはっきりせず, その外 郭は上述の電子密度の比較的高い部分との境界は かならずしも明確ではない。一般に塊状物を有す
る顆粒は多くはなく，明るい顆粒の間に点在する 程度であるが，細胞によってはこの種の顆粒を多 く有するものがある。分泌顆粒では限界膜がはっ きりと顆粒の全周を取り巻いているものが多い が,このほかに限界膜が部分的に明らかなもの, さ らにはほとんどこれを認めがたいもの等がある。 ゴルジ装置の近くには，ゴルジ小胞が数個並んで 一つの顆粒に融合する像も認められた。

分泌顆粒はおのおのが離れているのが普通であ るが, しばしば癒合する顆粒が見られる。顆粒の 大きさは $0.5 \mu$ 以下から $2.0 \mu$ 程度以上まで種々 であるが, 成熟顆粒は $2 \mu$ 前後と思われるので, 成熟するには融合も見られるし，さらに分泌塊と なったものも認められる。

終末細胞の分泌顆粒の腺腔への 放出像はあまり よくみられないが一般には細胞頂部が陥凹し，す でに分泌顆粒の形を失った顆粒成分の放出を思わ れる像が見られる。1例であるが分泌顆粒の一部 が腺腔に突出し，アポクリン分泌様突起を示す像 が見られた。

細胞質にはときどき液胞が見られるが，これは 明らかに限界膜を有し, 内部は明るく, 分泌顆粒 の明るいものよりもさらに電子密度が低い。それ らの液胞のほかに比較的電子密度の高い小胞状物 を有するものがある。液胞には細胞小器官が密接 することがなく，細胞基質が被膜状をなして小器 官と隔てている。また液胞に分必顆粒および電子 密度のより低い細胞質が突出して液胞と融合し, さらにその中に放出されるような形態が認められ る(図7)。

ライソゾームがしばしば認められる。これらの 構造物は細胞全体に分布しているが，多くは核上 部に見られる。なお一般に dense body と称され ているものはゴルジ装置付近に集中する 傾向があ る。dense body としての形態にも非常に多くの 種類が認められる(図 8)。球状, こん棒状, マユ 状，覀鈴状がその例で，ほかに若千それらの変形 もみられる。それらは内部の電子密度の高い成分 を含むもの程, 限界膜の著明なのが特徴である。 なお限界膜と電子密度の高、成分との間には, わ ずかに低い電子密度を示す部分がある。dense 
body は比較的小型で, 出現頻度が高い。これら の dense body 以外のライソゾームはその電子密 度が小型の dense body 程高くなく, 出現頻度は 低く，形態もさまざまである。

SOTELO PORTER $(1959)^{70)}$ が初めて記載した multivesicular body も見られ，その内部構造の一 部が電子密度を増して dense body に変っていく と思われる像また dense body が multivesicular body 様形態をなしたと思われる像も認められる (図 8)。さらに cytolysosome 様構造物として, そのうちに粗面小胞体を含むもの，あるいは単に 細胞基質状のものを含むものもある。そのほか不 規則なラメラ状物を含み, 周囲に電子密度の高い 物質を有する型もある。

dense body はゴルジ装置付近によく見られる のであるが，同装置から直接形成されるという明 らかな像は得られない。

細胞質には以上のようなもののほかに，ときど き 1 ないし数個の脂肪滴がおもに細胞基底部の層 板構造をなした軎状の粗面小胞体間に見られる。

中心子または中心小体が、ゴルジ野内またはゴ ルジ装置に接近して，あるいは細胞頂部にもしば しば見られる。中心子は双心子として互いに直角 をなすもの，あるいは一つだけのものも見られ る。中心子の横断されたものは明らかに 9 対の微 細小管からなるのが認められ，中心子の出現頻度 はかなり高い。

細胞頂部および側部には，後述する接着装置と してのデスモゾームと関係するトノフィラメント (または cytoplasmic filament) と称されている細 線維または線維束が縦横に走っているのが見られ る。この細線維に由来すると思われる細線維束に 横紋構造を有するものが 1 例認められた(図 9 )。 その横紋構造は本細胞では電子密度が高く明瞭 で, $12 \mathrm{~m} \mu$ 程度の幅をもった横紋と, その横紋と 横紋との間にさらに 細い $2 \sim 3$ 本の横紋を有し, それらは大体において等間隔のように見受けられ る。この太い横紋の周期は約 800 900 ゙̊̊ある。

終末細胞間にはしばしば 明瞭な細胞間分泌細管 が認められ，これには細胞の長径の $2 / 3$ 程度までは いり込むむのがある。このような細管が終末細胞
内にはいり込んで 細胞内分泌細管のような観を呈 する場合がある。腺腔の広さおよび細胞間分泌細 管の太さは小で $1 \mu$ 前後である。この細胞は腺腔 および細胞間分泌細管内に多数の 䋘毛様突起を出 しており，そのために腺腔内および細管内は複雑 になっている。絨毛様突起は長さ約 $0.5 \mu$, 幅約 $0.1 \mu$ 程である。その内部には細線維と思われる ものが認められた。

腺腔および細管内には 分泌顆粒成分と同様のも のが見られるが，電子密度はそれより低く液胞の ものと同じ程度である。

細胞間の接着装置としては, 腺腔側には jun・ ctional complex が見られ，それより深部にはと ころどころ嵌合があるが，その発達は著明ではな い。細胞間隙はほとん見られず，したがってヒ

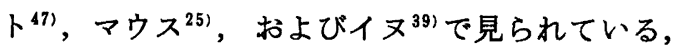
間隙内における絾毛様突起は認められない。ただ 乙無髄神経終末のはいり込む像はときどき見られ る(図10)。

細胞基底面で, 細胞間の接着部位に近い小部分 に, 絨毛突起様の基底陥入があるほかは大部分は 平滑であるが，その一部分に基底陥入の形成され た数例を見ている。細胞基底は明るく無構造な介 在層を介して基底膜に接する。この基底膜は断裂 することなく連続する。この基底膜および介在層 内に無髄神経終末がはいり込み，しばしば細胞基 底に接する。また筋上皮細胞が腺細胞に接してい るのがときどき見られる。

\section{2. 終末部基底明調細胞}

この細胞は終末細胞間の 基底に位置するもの で，小さく球状のものから終末細胞の形態をなす 大きなものまで, 種々の段階の大きさのものが見 られる。この種の細胞の小形のものは細胞質がと ぽしく, 細胞小器官もごくわずかで, 球状の糸粒 体が $2 \sim 3$ 個, 少量の遊離のリボゾームおよび小 胞を有する。また dense body がときどき認めら れる。本細胞は細胞体が大きくなるに従って終末 細胞間に深く進入し, 粗面小胞体, ゴルジ装置が 出現する。さらに大きなものでは粗面小胞体の䧶 がふくれて, 空胞状を呈し, その量む増す（図11, 12)。遊離リボゾームとともにポリゾームも見ら 
れるようになる。より発達したるのでは粗面小 胞体が亯が縮小, 扁平化して層板構造を有する (図13)。ゴルジ装置も発達し，分泌顆粒の形成が 見られる。顆粒は終末細胞におけるように明る く，電子密度の低い内容を有する。細胞質の電子 密度も終末細胞のものと同じ程度に近づく。細胞 の核は小型細胞では 終末細胞の半分程度の大きさ で, 形も球形，棈円形など種々であるが，層板構 造をなす粗面小胞体を有する細胞では，細胞体が 終末細胞と同様の大きさであり，核も細胞基底側 に偏在するようになる。核には核小体は認められ ないが，核内封入体として nuclear body を有す る例が見られた。またこの細胞の分裂像を思わせ るものが 1 例得られた。分裂様式は無㫧分裂であ り，細胞体および核が亜鈴形をなし，分裂途上の 像であると思われる。このような形の核の一半を 含む一方の細胞質には小胞, リボゾーム, dense body が, 他方には小胞, リボゾーム, ライソゾー ムおよび粗面小胞体の毫状を呈するものが見られ た。これらの基底明調細胞は明らかな接着装置を 示さないが，ときに隣接細胞との間に嵌合様の構 造を示すだけで，あたかも遊離細胞のような観を 呈する。

3. 終末部粘液細胞

著者は 1 個体で粘液細胞の出現を認めた（図14, 15)。細胞体は 終末細胞より大きくときに 2 核性 のものがある。外形はふくらんだピラミッド形を 呈し，核は扁平な長棈円形または不規則形を示し て細胞基底部に偏在する。細胞基底部には亭状の 粗面小胞体があり，層板構造，管状あるいは液胞 状を呈する。核上部には分泌顆粒, 著明なゴルジ 装置が分布し, その間に管状の粗面小胞体, 遊離 のリボゾームおよびポリゾームが見られる。粗面 小胞体内部には比較的電子密度が高、物質が 満た されている。この像は他の細胞の粗面小胞体と明 かに異なる。

釆粒体は比較的小形で, 電子密度が高く, 細胞 全体に分布する。

ゴルジ装置はよく発達し，ゴルジ野をなすもの が見られる。ゴルジ犦は数層みられ，終末細胞， 峡部細胞におけるよりも長く伸びて大きい。ゴル

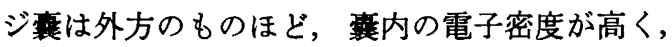
終末細胞や峡部細胞で見られるゴルジ空胞は見ら れない。内方に見られるゴルジ小胞はやはり比較 的電子密度の高い内容をもっているが，この細胞 では外方に多く見られる。なお内方のものは終末 細胞とは違って，むしろ少し大きい傾向を示す。

分泌顆粒は $3.6 \mu$ 以上に達するものもあるが, 平均 $2.6 \mu$ で終末細胞のものより大きく, 顆粒内 容は一様に電子密度が低い。この顆粒は限界膜を 有し，おのおの独立しているが，ときどき融合様 の形態を示すものがある。この分泌顆粒とゴルジ 装置との関係は明らかで, 形成途上の像が本装置 に認められる。

ライソゾームとして dense body が存在する が, 終末細胞, 峡部細胞, 線条部明調細胞に比較 して少ない。その他, 脂肪滴, 中心小体も見られ た。

この細胞群は腺腔を形成し，頂部には絨毛様突 起を有する。細胞間分泌細管は形成されないが, 細胞頂部がくぼんで䋐毛様突起を有する腔を形成 しているのが見られる。

細胞間の接着は頂部では junctional complex を示し，それより樑部では直線的な接着面を示す が，ところどころに嵌合およびデスモゾームが見 られる。細胞基底面には接着面で見られる嵌合様 の形態をなす細胞膜の陥入がところどころに見ら れ，膜が陥入したその頂部から鎖状に並んだ小胞 が見られる。これは接着面の嵌合部でも同様に認 められる。基底面に注細胞膜の外側に介在層を介 して基底膜が見られ，さらにこの基底膜が峡部細 胞の基底膜と連続する像が認められた。筋上皮細 胞，神経終末が分布する像は認められなかった。 この細胞には本来の峡部細胞との間にデスモゾー ム，嵌合などの接着装置が認められるので，耳下 腺細胞の一員であることがわかる(図 15)。なお本 来の終末細胞(墏液性細胞) と混在することなく， 本細胞だけで終末部を形成する。

\section{$\mathrm{B}$ 峡 部}

峡部は発達がよく，長い。峡部の細胞は峡部細 胞, 基底明調細胞, 筋上皮細胞の 3 種に区別する ことができる。筋上皮細胞についてはCで述べる。 


\section{1. 峡部細胞}

峡部細胞は他の動物の 唾液腺峡部細胞よりも分 泌顆粒の形成が盛んで, 分泌活性が高い。細胞は 立方形，ピラミッド形あるいは扁平な直方体形を 呈し，終末細胞より小さい。な終末部に隣接す るものはやや大きく，線条部に近いものが小さい 傾向を示す。さらに終末部に峡部細胞の混在する 像はさほど珍しくない(図16)。

核は楕円形ないし長棈円形を示し，その表面が 凹凸がはげしく，細胞基底に偏在するが，その外 形の不規則であることが特徴である。核の内部 構造は終末細胞 と同様で，核内封入体としての nuclear body のごときも著明である。 nuclear body の出現頻度は高く, Type I, II, III (図 3, 4，5）の各型が見られる。

細胞質は多数の特異的な 分泌顆粒とリボゾーム を含有し，そのためは細胞の電子密度は高く， 終 末部細胞より暗くなる(図16,17，19，20)。リボ ゾームは遊離のものが多いが，ポリゾームをなす ものもよく認められる。粗面小胞体では，空胞状 または管状を呈するものは分泌顆粒間および核上 部に多く見られるが，僅状のものが層板構造をな し，よく発達したものが細胞基底部に見られる。

系粒体は球状，棈円状を呈して細胞全体に散在 するが, 核附近により多く認められる。ゴルジ装置 は発達がよく，数個のものによってゴルジ野の形 成されているのが見られる。またゴルジ野の形成 されない細胞では，核上部に二,三個のゴルジ装置 が細胞頂部に対し弧を描いて位置するのが見られ る。ゴルジ装置を構成するゴルジ輁, ゴルジ空胞, ゴルジ小胞の分布は 終末細胞におけると同様であ る。ゴルジ空胞と空胞状粗面小胞体とが混在する のが見られ，後者から前者に移行するような像も しばしば認められる。終末細胞と同様にゴルジ啧 の一端がふくらんでいる像がしばしば見られるが これは分泌顆粒形成を示すものと考えられる。

分泌顆粒は大きさ約 $1 \mu$ で多くは限界膜に囲ま れた球状をなすが，中には多角形のものも見られ る。その内容は顆粒全体が明るく, 終末細胞の顆 粒の一型を思わせるもの，それよりやや電子密度 が高く均質なもの，やや暗調な内容のなかに非常
に電子密度の高い大小の塊状物を含むもの, さら に顆粒全体が電子密度の高い均質なものからなる もの，このようなものが 1 ないし数本の亀裂によ って 2 ないし数個の小部分に分けられるもの, 中 央部が明るく周辺部が暗い 環状（数力所に亀裂が 見られる)を呈するもの，類結晶を含むものなど， 種々のものが一つの細胞内に認められる（図18, 19)。大きな塊状物または類結晶を含む，ほぼ球 状の顆粒はその外形に変化を来たし, 多角形を呈 する。類結晶が含まれる場合には, 結晶が顆粒の 周辺に位置するために，顆粒のその部分の縁が平 坦となって，全体の形が半球状を呈する(図20)。 特殊な例として分泌顆粒の大きさ $(1 / 8 \mu)$ と形態な らびにその電子密度が, 後述する線条部明調細胞 のものとよく似る顆粒を有する細胞を見ている (図21)。

細胞基質には明らかに類結晶が存在するが，こ れは棒状で, 顆粒内の塊状物と同程度に電子密度 が高い。類結晶は棒状の先端に明確な面角を示す (面角は模型図 2 で示すような角度を呈する)。ま た内部構造は電子密度が 高いために明らかでな い。2 例の複合結晶が見られたが，1例は両結晶 とも同じ電子密度を有する「ト」の字形を示し（図 18), 他は針状の電子密度の高い長短 2 本よりな り，長いものにはその両側に，短かいほうには長 いものに接する側に，それぞれ電子密度のやや低 い部分が認められる(図19)。

一方, 分泌顆粒の放出過程における一つの段階 と思わせる像がしばしば認められるが，細胞の深 部から管腔側に向って次のような移行が認められ る。すなわち分泌顆粒の中央に電子密度の高い塊 状物を有し, その周囲に線維状のものが取り巻く 像, 顆粒中に線維状物のみを有するもの, 分泌顆粒 の変形としてできたと思われる液胞状のものの中 に線維状物を有するもの, 液胞状のものの融合す る像などがそれである。後 2 者は細胞頂部に多く 見られる。すなわち以上のように形成された線維 状物が管腔に放出される(図22)。換言すると分泌 顆粒そのものが放出されるのではなく，上記の過 程を経るので，管腔内がそのような線維状物で満 たされている像が見られる。なおこの線維状物は 
ゴルジ装置の售内に見られることがあるが，この ことは分泌顆粒が該軎によって形成されることを 証明する一つの証拠と考えられるであろう。

液胞状のものはおもに 細胞頂部に見られるが, 終末細胞におけるものと同様に，その周囲にはリ ボゾームなどの細胞小器官が見られず, 細胞基質 そのものによって取り巻かれる。上述の液胞状の ものは顆粒に由来するが，そのほかにこれとは別 種の液胞が存在する。それは内容が明るく線維状 物を含まない形態のもので，ゴルジ軎に由来する のか, 他の細胞質に由来するのかは不明である。ま たこの種の比較的大きい液胞内には, 終末細胞で 認められたと同様に明るい分泌顆粒が突入するよ うな像および液胞同志が相接する像が見られる。

細胞質には上記のもののほかに 終末沺胞と同様 に種々な形態のライソゾームが認められる。dense body として 終末細胞で述べた型はもちろん，そ の他の形態も見られる。 multivesicular bodyでも その形成がゴルジ装置と密接な関係を有する像が 認められる。ある細胞ではゴルジ装置の最内層に 相当するゴルジ震がC字状をなして，そのうちに ゴルジ小胞を抱鹤する状態を示すのが見られ，こ のときのゴルジ軎内には電子密度の比較的高、物 質を有する(図23，24)。

大きなライソゾームでその内容が 複雑な構造を 呈するものがあるが，終末細胞で見られたような 類結晶を含むものは認められなかった。細胞頂部 表面には絊毛様突起を有するが，あまり著明でな く，それの認められないものもある。またそれが 存在する場合には腔内の分泌物に圧迫されるため か，細胞表面に平行になっている。

隣接細胞間には細胞間分泌細管は形成されな い。細胞間の 接着は終末細胞と同様に腺腔側に junctional complex を有し, これょり深層では嵌 合が見られ，さらにデスモジームが管腔よりにと きどき発達しているのが見られる。基底面は終末 細胞と同様に滑らかであり，筋上皮細胞は終末部 よりも多い。峡部細胞が筋上皮細胞と接する面お よび峡部細胞間の 嵌台部には小胞が多く認めら れこれらは鎖状にならび，あるいは pinocytotic vesicle を思わせるような状態をなす。
細胞には無髄神経終末の分布が見られるが，終 末細胞におけるように多くはない。基底膜は終末 細胞におけるものと連続して峡部細胞をおおう。

2. 峡部基底明調細胞

この細胞は 終末部基底明調細胞の小さな球状の ものと類似し，峡部細胞間の基底に位置する。細 胞質にとぼしく, 細胞小器官として, 系粒体, 遊 離リボゾーム，小胞を少量ずつ含むにすぎない。 終末部においては種々の大きさの該細胞が認めら れたが，峡部では 3 例にすぎないけれどもすべて 小さな球状をなすもののみである。

\section{C 筋上皮細胞(籠細胞)}

筋上皮細胞は峡部細胞， 終末細胞の細胞基底に 存在するが，峡部において比較的多い。細胞質は 核の位置する部位に多く，細胞は全体として紡錘 形をなす。この細胞 1 個が数個の峡部細胞または 終末細胞に接している。細胞核は一般に長棈円形 で, nuclear body を有するものもあり，その場 合 Type I, II である。細胞小器官は核周辺に分 布し，遊離リボゾーム，ポリゾームが見られる が, 粗面小胞体の発達は悪く, ときどき見られる 程度である。

糸粒体は他の細胞におけるより小型で， 円形， 棈円形をなす。ゴルジ装置はよく発達し, 典型的 な像を呈する。その他, 液胞, ライソゾーム, multivesicular body, 中心小体を有するものが見 られた。これらの細胞小器官の外方には筋細糸が 細胞膜に沿って分散する。ところどころに電子密 度の高い部分が見られるが，これは平滑筋線維に おける黒斑に相当するものであろう。細胞外方は 基底膜でおおわれ, 内方は終末細胞, 峡部細胞の 基底細胞膜に接着する。筋細系の分布は 2 種に分 けることができる。すなわち細胞基底部だけに分 市するものと基底部および内方部の両部に分布す るものとがある。細胞膜直下には小胞が多数配列 するのが見られる。それらの小胞は $0.08 \sim 0.10 \mu$ の大きさを示し, きわめて低い電子密度を有す る。また小胞が細胞膜と連続する像がしばしば認 められ, pinocytotic vesicle 状を示す。さらにこ れらの小胞間に液胞が見られ，これもまた細胞膜 と連続するのが認められる。小胞の分布は細胞基 
底側に多く，内方側にはわずかで，認められない ものもあるが，細胞によっては基底側にも全く存 在しない場合もある。筋上皮細胞と峡部細胞との 接着がデスモゾームによって行なわれている像が 認められたが，一般にはそのような接着装置は多 くは見られなかった。

$\mathrm{D}$ 峡部と線条部との接続部

この部位の細胞は終末細胞に隣接する 部分の細 胞に比較して小型であり，細胞質の電子密度が低 い(図25)。内部構造は種々な形態を示すが，全体 的に粗面小胞体および ゴルジ装置は典型的な形態 を示さない。この種の細胞は次のような各種の型 亿分けることができる。1）細胞質が少なく粗面 小胞体，遊離のリボゾームをわずかに有し，系粒 体は比較的多いが，分泌顆粒を含有しないもの， 2）分必顆粒を有し，ゴルジ装置が見られるもの (図25)。2) の型の細胞 はさらに二つに分けられ る。その一つは峡部細胞本来の比較的明る、分泌 顆粒とそれよりやや小さく電子密度がきわめて高 く，大きな dense body を思わせる顆粒とをもつ もので，明るい顆粒の方が多い。ただしこの 2 種 の顆粒は同一成分なのであるが，その量の違いで 電子密度を異にするので，この意味から同種の顆 粒と考えることができる。これらの顆粒には放出 末期の像と考えられる 線維状物を含有するものお よびそれらが 融合したと思われる像がしばしば見 られるが，このようなものは峡部細胞の分泌顆粒 におけると同一物 なのである。他の 1 種は上述の 2 種の顆粒とともに 後述の線条部明調細胞頂部に 見られ，小胞状の分泌顆粒に相当するものを含む 細胞である。この種の細胞では峡部細胞における 顆粒の量は少なく，ゴルジ装置には扁平なゴルジ 䧶が見られず，ふくらんだ空胞状を呈する。以上 によってこの細胞は 2 系統の分泌顆粒を形成する 能力を有するのではないかと想像される。3）この 細胞は遊離のリボゾームまたはポリゾームを多量 に有し, 細胞質の電子密度が非常に高い。峡部細 胞型の明暗 2 種の分泌顆粒を少量含有する。4)こ の細胞は基底陌入，系粒体の特異な分布を示し， 線条部明調細胞の形態を呈する。ゴルジ装置はゴ ルジ䯧が層板構造をなし，空胞状粗面小胞体から
出芽によって小胞が形成される像が見られる。こ の空胞状の粗面小胞体はときには ゴルジ空胞に隣 接し，直接ゴルジ空胞に移行するように見受けら れるような像を呈することがある。以上 4 種の細 胞ではいずれもその頂部に緁毛様突起が見られる が，著明ではない。細胞間の接着は管腔側には junctional complex を有し，それより深部に嵌合 とデスモゾームがところどころで見られる。細胞 核には nuclear body の Type I を有するものが 見られる。細胞基底には基底膜が見られるが，筋 上皮細胞，神経終末の分布は明らかでない。

\section{E 線条部}

線条部は明調細胞，暗調細胞および基底明調細 胞の 3 種からなる。

1. 明調細胞

円柱形を呈し，細胞質が明るく，基底陥入を示 す(図26)。核は細胞中央より頂部側に位置し，終 末細胞の核より明るい。核膜に集積する異質染色 質には電子密度の高いものと低いものとが 観察さ れる。この細胞の核にも nuclear body が認めら れ, Type I，IIが区別される。細胞質は明るく， 遊離のリボゾーム，ポリゾームが 細胞質全体に分 散している。粗面小胞体の発達は悪く，わずかに 小さな空胞状のものがあるのみである。核上部に はゴルジ装置, 球形の糸粒体，小さな液胞があ る。ゴルジ装置は 2 ないし 3 個見られるが，典型 的なものまで発達せず, ゴルジ小胞, ゴルジ空胞は 認められるが，ゴルジ䧶が層をなす形態はとらな い。このようなゴルジ装置の構造も明調細胞の特 徵といえる。核上部細胞質ではトノフィラメント が細胞小器官の間を縦横に走る。このトノフィラ メントの線維束でも 終末細胞で記載したと同じよ うな横紋を有する像が 1 例観察された（図27）。太 い横紋の周期は 800 900 ̊で明 らかであるが， その間の細い横紋は終末細胞におけるよ5に明ら かでない。その他, ライソン゙ーム, dense body, 中心小体, multivesicular body などがしばしば認 められる。

細胞頂部付近には 0.1 ないし $0.2 \mu$ 位の大きさ で，中等度の電子密度を有する 分泌顆粒または小 胞（以下分泌顆粒とする）が集中している像が観 
察される。この分泌顆粒は，細胞間の接着装置に 由来する細線維束 (これは intermediate junction に連なり，管腔面に並行して配列する） あるいは アポクリン分泌様突起 (または bleb 様突起) の有 無などに関連してその分布状態を異にする。すな わち突起，細線維束のないものでは顆粒は管腔面 值下に配列するが(図28)，このような顆粒を全く 欠く細胞も見られる(図29)。突起が形成されてい るものでは笑起の基部に見られ，1例においては この基部の顆粓間に 細線維束の一部が見られた (図27)。細線維束が管腔面に平行して現われたも のでは顆粒がその下に見られ(図29)，細線維束の 切れ目を通して頂部に出ているものもある（図 30)。細胞頂部には長さ $0.75 \sim 1.00 \mu$ 位，幅 150 $\mathrm{m} \mu$ 位の緁毛様突起を有するが, このものはアポ クリン分泌様突起および 細線維束を有するもので は見られない。ただし突起を有しない細胞でも， 䋐毛様突起の発達しないものがあり，これも顆粒 と同様に，突起および細線維束の有無に関係する ような像を呈する。さらに突起および細線維束を 欠く細胞で, 䄉毛様突起は認められるが, 分泌顆 粒の分布が見られるものと，見られないものとが 観察される。このような所見から 分泌顆粒の分 布, 分泌突起, 絨毛様突起および細線維束はそれ ぞれ密接な関係を有し，細胞機能によって，その 形態，分布，量等に変化を来たすものと想像され る。

基底陥入は核に達する程に深くはいり込んでい る。陥入した 細胞膜にはさまれる細胞質 (FC) に は多くの円形，棈円形の采粒体が平行にならび， 特異な像を呈する。その大きさは大小種々で, cristae はよく発達するが，系粒体内顆粒は認めら れない。(FC)には系粒体のほかに, dense body, リボゾーム, ポリゾーム, 小さな空胞状の粗面小 胞体, 小胞, 細線維(トノフィラメント)などが見 られる。細線維は核付近では横に走るが, (FC) は縦走する。この縦走する 細線維は(FC)のすべ てにはいり込むのではなく，細線維の見られない 部分があり，この線維の分布が(FC)の明暗を示す ように思われる。一般に隣接細胞の基底陥入は互 いにからみ合うものであるが，その相接する細胞
膜間にはところどころにデスモゾームの形成され ているのが認められる(図31)。陥入した細胞膜の 一部から小胞が鎖状をなして 形成されている像が 見られる(図32)。

光顕像ではがれたように見える 部分は電顕像で は一見して明るい大小さまざまな 液胞状のものが 集合したように見えるけれども，その内部にはリ ボゾーム，禾粒体などがまばらに散在し，細胞膜 をたどるとこれらのものは 細胞質そのものと連続 していることが確められる(図33)。

細胞間の接着は大部分が 明調細胞間にあるが， 管腔側には junctional complex があり，それよ り深層では嵌合があり，ときどきデスモゾームの 発達している像が認められる。intermediate junction にはすでに記した細線維束が付着する が，細線維束はデスモゾームに付着するトノフィ ラメントより細く，かつ密集する。またこの細線 維束は増减することがあり，トノフィラメントよ り明瞭に観察される。

細胞基底部の細胞膜の外側には介在層を介して 基底膜がある。またこの細胞膜には神経終末の分 布および筋上皮細胞の接着は認められない。

2. 暗調細胞

この種の細胞は明調細胞間に散在する 程度で, はるかに少ない(図26)。その電子密度は明調細胞 よりかなり高く，全体として暗調をおびる。核は 細胞基底側に偏在し，棈円形ないし円形，不規則 形などで， nuclear body も認められる。

核上部の細胞質は明調細胞と同様であるが，細 胞頂部には電子密度の低い小胞が集中しており， 明調細胞における 電子密度の比較的高い顆粒は認 められない。

細胞基底は明調細胞と明らかに違って，細胞が だんだん細くなり，基底膜にまで達せず，基底宿 入を形成しない。

暗調細胞と隣接細胞との結含は管腔側では junctional complex が形成され, intermediate junction には明調細胞におけると同様に, 細線維 束の付着する像が見られる。それより基底側では ときどきデスモジームがあり，さらに暗調細胞の 細胞質の一部がところどころ長い突起を作って隣 
接する明調細胞に突入しているが，細胞基底部で は突起の発達が特に著明である(図34)。暗調細胞 同志間にはそのような嵌合は認められない。

1 例であるが暗調細胞で典在的なゴルジ装置を 有し, 粗面小胞体が発達して層板構造を示し, 細 胞頂部には峡部細胞の分泌顆粒を思わせるものが あり,さらに細胞底部が 基底膜に達するものが見 られた (図35)。

3. 基底明調細胞

この細胞は 1 例に遭遇 しただけであるが（図 31）それは明調細胞の 基底部細胞間で, 暗調細 胞の基底細胞膜と接する位置に存在するものであ る。細胞は卵形で核はやや小さく, その一部に深 、陥入が認められる。細胞質は少なく, 発達の悪 、粗面小胞体, 遊離のリボゾーム, ポリゾーム, 釆粒体, 小胞, 中心小体および 細線維などが認め られるが, その細胞小器官の発達状態から推測し て，未分化な細胞と思われる。基底明調細胞は隣 接する暗調細胞とは指状突起による嵌合およびデ スモゾームによる接着, また明調細胞とは指状突 起による哚い嵌合を行なっている。この細胞はそ の位置からすれば終末部および峡部における基底 明調細胞に類似するが，細胞質の電子密度がやや 高く, 隣接細胞との接着が著明である点でそれら と異なる。

\section{F 神経終末の分布}

小葉間結合組織内にはしばしば 無髄神経線維の 横断，縦断あるいは神経終末の横断と思われる像 が見られる。その神経線維の内部構造は神経細線 維が神経線維の走向に平行に分布し，糸粒体， dense body, 液胞, 小胞および少量の遊離リボゾ 一ムなどを有する。小胞は神経終末に近づくに従 い多くなり，神経細線維の量は少なくなる。また 無髄神経にはシュワン氏細胞を伴うものも見ら れ, 神経線維はこの細胞に接着する。神経線維お よび終末は介在層を介して基底膜におおわれる。 以上の神経終末断面の構造として 2 種のものが見 られる。一つは $\left(V_{1}\right) 500 \sim 560 \AA ̊ 丿$ の比較的電子密 度の高い小胞を多く含み，しかもその小胞は密に 集合して結晶様の配列を示しているが，他の一つ ・ $\left(\mathrm{V}_{2}\right)$ はその内容は、電子密度が低い $1000 \AA$ または
$1500 \AA$ 程度の小胞 と $630 \AA$ 程度 で上記 $\left(V_{1}\right)$ の小 胞よりやや電子密度の低い小胞とが散在し，その ほか釆粒体と少量の神経細線維とを有する 終末で ある。腺細胞には神経終末がしばしば接着する像 が認められる。大部分のものは終末細胞の基底細 胞膜に接着するが，峡部細胞に接着する像は 1 例 得ただけであり，線条部ではそのような像を認め られなかった。終末部では細胞間にはいり込んで いるものが数例認められた。終末細胞基底に分布 するものは，その部分の細胞膜に接し， 細胞間に おりるものは両細胞膜間に位置する。これらの神 経終末と終末細胞の両形質膜には 特別な構造を形 成しないで接着しているが，その間には約 $200 \AA$ ほどの間隙がある。神経終末内にはその内容の電 子密度がやや高い 300 500 ̊̊ ほどの小胞と 800 $1000 \AA ̊$ および $1200 \sim 1500 \AA ̊$ ほどの内容の明るい 小胞，系粒体が散在するが，小胞の特別な集合形 態は認められない。1例において無髄神経線維束 が 1 個のシュワン氏細胞を伴って 終末細胞に接近 しているのが見られた(図36)。その際 1 本の神経 線維の断面の一端が，シュワン氏細胞と終末細胞 とに接着している像が見られた。これらの神経線 維においてもその終末には前述の 2 型 $\left(\mathrm{V}_{1}\right.$ および $\mathrm{V}_{2}$ ）が認められる。終末細胞に接着する線維は, 釆粒体と比較的多い神経細線維とを有し，小胞は 接着面の一部に数個集中するだけで，明らかに神 経終末よりは神経線維に近い形態を示す。またこ れらの神経線維は終末細胞をおおう基底膜に連続 した膜によりおおわれている。終末細胞には以上 のような神経終末のほかに, 神経線維が分布する 場合があると推測される。一方, 動脈の外膜に存 在する神経線維の終末には，他と異なる小胞を有 する(図37)。すなわち神経終末は多くは 500 600 Åの小胞を有し, それらのうちにその内部に電子 密度の高い芯状物質を有するものがある。さらに $1200 \AA ̊$ 位の大型の小胞, 糸粒体, 神経細線維など が見られる。

G 小葉間結合組織内の血管

小葉間結合組織内には前記の神経のほかに多く の血管が分布し, 小動脈, 細動脈, 毛細血管を区 別することができたが，細静脈と毛細血管との区 
別は明らかにすることは困難であった。細動脈は $5 \sim 6$ 個の内皮細胞からなり，周囲細胞の一部分 の断面が数個外方に存在する。内皮細胞と周囲細 胞との間に基底膜が存在し，その両側には電子密 度の低い介在層が認められる。また周囲細胞が存 在しない部分では，周囲細胞の外側に密着する厚 、基底膜と同様の膜が内皮細胞外方に存在する。 この膜は内皮細胞と周囲細胞との 基底膜が癒合し て形成されたもの(EP) と考えられ，このような場 所では (EP) はさらにその外側にある神経線維の 基底膜とも疮合する傾向を示す。なお両種細胞の 基底膜には断絶の像が見られない。内皮細胞にも 少量の粗面小胞体と遊離のリボゾーム, 系粒体, 液胞, dense granule とともに著明な小胞を有す る。この小胞と細胞基底側, 管腔側の細胞膜との 間には密接な関係が認められ, pinocytotic vesicle と考えられる。隣接する両細胞間には閉鎖堤が形 成され，その近くには境界褶譬 (marginal fold)が 見られるが，これに似た突起は細胞中央部付近で もしばしば認められる。内皮細胞は細胞質を比較 的多く含み, 細孔を有しない。

毛細血管には内皮細胞が二ないし数個見られる。 内皮細胞の外側には 周囲細胞の断面が現われる場 合と現われない場合とがあり，本細胞が少ないこ とを示している。内皮細胞と基底膜との間には無 構造な介在層が見られ, 膜は断絶しない。内皮細 胞の基底膜が周囲細胞の基底膜と癒合し $(\mathrm{P})$, 周 囲細胞付近で 2 層に分かれる像は, 毛細血管の場 合でも細動脈と同じである。なお $(\mathrm{P})$ は $(\mathrm{EP})$ に比 ベるとはるかに薄い。内皮細胞の細胞質は上述の ものと同様であるが，ゴルジ装置を有するものが 見られ，全体に小器官はより少量である。細胞は 長く薄く伸び，ところどころに細孔を有し，ここ に薄膜 (diaphragm) が架橋しているのも明らかで ある。小葉間結合組織内には以上のような血管お よび神経のほかに, 線維細胞, 肥満細胞, コラー ゲン線維などが分布する。

\section{総括および論議}

\section{A 終末細胞}

1. 終末細胞小器官の概観
諸種ホニュウ動物耳下腺の超微細構造について の電子顕微鏡的研究はすでに多くの先人によって 行なわれているが，著者の対象としたハムスター の耳下腺に関しては SHACKLEFORD·WILBORN (1968) $^{18)}$ がマウス，ラット，リスおよび desert rat（2 種）とともに本動物を使用しているのを見 るだけで，その記載は簡単である。かれらによる とハムスターの終末細胞はよく発達した 粗面小胞 体, 核上部に位する不連続なゴルジ系, 細胞間分 泌細管を有し，核は棈円形または円形で基底に位 置すると述べている。著者の所見も大体それに一 致するが, 発達した粗面小胞体は位置が限定され る傾向を有し基底部では層板構造をなすが，核上 部では小胞状のものが顆粒間に見られる。層板構 造は細胞基底部の細胞膜または隣接細胞側の細胞 膜に平行して配列し, 粗面小胞体の末端はゴルジ 装置またはゴルジ野近くで終る。しかし途中に分 泌顆粒, 糸粒体が存在する場合には, そこで中断 される。かれらは注目していないが, 粗面小胞体 に付着しているリボゾームのほかに, 遊離のリボ ゾーム，ポリゾームが細胞全体に分布する。しか し数個のゴルジ装置が円形をなして配列するゴル ジ野および細胞頂部の近くではそのような 遊離の リボゾームおよびポリゾームは少ない。

\section{2. 分泌顆粒の形態}

KURTZ (1964) ${ }^{58)}$ はラットの耳下腺終末細胞にお いて 2 種の細胞を区別した。一つは広がった粗面 小胞体と均質な分泌顆粒およびしばしばそれらが 融合して大きな不規則な塊になったようなものを 含み，細胞基質は電子密度が高いのが特徴であ る。他は細胞基質の電子密度が低く，分泌顆粒が 互いに分離していて融合しない型である。八ムス ターではこのような細胞型の区別は明らかでない が，基底部の粗面小胞体が著明な 層板構造を示す もの，層板構造をなす粗面小胞体の量が比較的少 ないもの, 多数の分泌顆粒を含むもの，少数しか 含まないもの，ゴルジ装置がゴルジ野をなすも の，あるいは単に数個のものがまばらに分布する ものというょうに， 細胞小器官にいろいろな発達 段階が認められる。しかしこのようなものは細胞 機能の相違によるものであって，本質的な相違で 
はないと考えられる。

SCOTT PEASE (1959) ‘ はラットの耳下腺終末細 胞で低く電子密度を有する物質な顆粒と, 比較的 電子密度の高い物質からなる 顆粒およびこれらの 両者の移行型とを区別している。また同氏らは電 子密度の低、顆粒はその細胞の分泌機能が 高、時 期のものであり, 電子密度の高い顆粒は分泌機能 の低い時期の細胞におけるものであって，常に細 胞頂部に分布するとしている。RUTBERG (1961) ${ }^{25)}$ はマウスの耳下腺終末細胞の 分泌顆粒を 1) 電子 密度が低く均質な顆粒，2）顆粒の外周部がわず かに電子密度が高く, 内部が低、顆粒，3）内部に 電子密度の高い塊状物を有する顆粒の 3 種を区別 している。KURTZ (1964) ${ }^{12)}$ はラットにおいて, RUTBERG の第 I, II 型に相当するものを記載し ているが，第而型については言及していない。 WILBORN·SCHNEYER (1970) ${ }^{22)}$ はラットにおいて, 電子密度の高いもの, 低いものおよび周縁部の電 子密度が高く，中心部が低いものを記載している が，上述の RUTBERG の分類に一致するものとそ うでないものとがある。以上のように絜歯類では ほぼ同様の形態を示すが，ハムスターでも RUTBERG の示す三つの型に分類される(図1，2)。た だし第 II型とされるものでは 比較的電子密度の高 い部分が，ラットおよびマウスでは周縁部に環状 をなして見られるのに対し，ハムスターでは顆粒 の一端に集まる傾向を示し，環状を呈しない（図 2 )。踭齒類以外の動物では, MAKITA et al. ${ }^{7}$ が ウマの耳下腺終末部の分泌顆粒は電子密度が高く 均質であるがときに中等度の電子密度を示す半月 状部が，高い部分に接して見られるとしている。 また SHACKLEFORD・WILBORN はウシの耳下腺 で電子密度中等度の顆粒と高い顆粒とを区別して いる。著者はイヌおよびネコの耳下腺では，一般 に中央に電子密度の高い輪郭の明瞭な大きい球状 の芯を有し, その周囲は電子密度が低く明るい顆 粒を見ている。またヤクザルの耳下腺はイヌおよ びネコとほぼ同様で，芯状物質の輪郭が明瞭であ る点では一致するが，その大きさの小さい点では 異なっていることを認めている(未発表)。

このように分泌顆粒の形態について見ると，、
ムスターと他の鳌歯類とは大体似た形態を示す が，絜歯類以外のものとは相違することがわかる。

3. 分泌顆粒とゴルジ装置との関係

分泌顆粒形成については多くの研究がなされて いるが，唾液腺に関しては単に少数の先人が分泌 顆粒とゴルジ装置との関連性を 認めているにすぎ ず，顆粒の形成される過程 をつまびらかにしてい ない。著者がハムスターで観察したところによれ ば，分泌顆粒第 I および第 II 型では明らかにゴル ジ毫の一端と顆粒限界膜とが連なっている像が 認 められること，および第而型の顆粒もゴルジ装置 付近またはゴルジ震に接している像がしばしば認 ひられることなどから，顆粒はゴルジ装置におい て形成されると考えられる。なお細胞機能すなわ ち粗面小胞体におけるリボゾームの合成機能およ びゴルジ装置の機能の差異などによって，顆粒の 形態的な違いを生ずるのではないかと考える。分 泌顆粒の形成について 黒住ら $(1963)^{72}$ は次のよう に述べている。すなわち粗面小胞体より出芽した 滑面小胞体はゴルジ小胞に転じ，ついで多くの場 合にゴルジ層板を形成する扁平业に接着してこれ に開口する。このようにして 粗面小胞体からゴル ジ装置に移送された分泌物質はゴルジ膜の機能に よって濃縮され，さらに新たに分泌物を添加され て電子密度を増し，扁平囊の末端にたまりこれが ちぎれて分泌顆粒となるか(下垂体の場合) あるい は扁平軎が全体として不整形にひろがりゴルジ空 胞の形をとったのち，さらに分泌物質によって充 実されて完成された 分泌顆粒に変る（膵外分泌腺 の場合）という。しかるにハムスターにおけるゴ ジル装置を観察すると，その外方（凸側）にはゴ ジル空胞, 内方 (凹側) には多くのゴルジ小胞が 分布し，その間に数層のゴルジ亳が位置する関係 にある。粗面小胞体の最も近くにゴルジ空胞が位 置し, この空胞に空胞状の粗面小胞体およびゴル ジ装置に面する側にリボゾームを欠く粗面小胞体 の混在しているものが認められる。さらに詳しく 調べると空胞状の粗面小胞体がリボゾームを失な いゴルジ空胞化し，これがいくつか融合してつい には一つの大きな輁に変わり，これがさらに扁平 化する像が追及できる。 
$\operatorname{HAM}(1969)^{73)}$ はゴルジ装置の外側に粗面小胞体 由来の小胞が集まってゴルジ鼠を形成するとし， また黒住らは小胞がゴルジ䒾に接着するとしてい るが,このような所見は著者は観察しなかった。 なお著者は 粗面小胞体より出芽により小胞が形成 される像を見ることができなかった。次にハムス ター終末細胞のゴルジ軎は 各層が同一電子密度を 示すものではなく，外方から内方に漸次密度が高 くなるもので, BEAM et al. (1968) ${ }^{74)}$ も coelenterate medusa の胃上皮細胞で同様な像を示して いる。しかるに著者が ハムスターの耳下腺で認 めた粘液細胞および Ham の腸上皮細胞で示すも のは，その関係がまったく逆になっている。こ のような 違いは細胞の 種類の 違いまたは 機能の 違いによるものなのかもしれない。次に著者は終 末細胞のゴルジ装置の内方に多数の小胞を認めた が, BEAM et al. (1968) \& styla の卵巣の test cell と coelenterate medusa の胃上皮細胞のゴル ジ装置内方に小胞を図示している。前者ではその 部位における毫の細断によって小胞の形成される ことを示し，後者は辁から小胞が膨出しているよ うな像を示している。著者は八ムスターに関する 限ぎり，この部位における小胞は，ゴルジ䧶の形 成にあたる要素とするよりは，むうこ震から分離 された要素であると考える。これは形成直後と思 われる分泌顆粒中に膜成分の含有 せられているも のを認めているが，これは小胞由来のものとしか 考えられないし，さらに分泌顆粒をいくつかの小 胞が取り册む像が見られることなどから推測され る。以上のように小胞はゴルジ装置内方に多く存 在し，ゴルジ豪より形成されると推測されるが, ゴルジ装置の外方および側方にも見られることか ら，粗面小胞体より由来するものがあるというこ とは否定できない。

4. ライソゾーム

ライソゾームの形態は多種多様で名称むきわめ て多く, 小川ら $(1970)^{75)}$ はライソゾームおよび類 似小体34種を記載している。八ムスターではその うち dense body がめだち, 数も多く，その形態 としては小球状, マユ状, オタマジャクシ状, 亜 鈴状，環状およびそれらの移行型が認められる。 dense body 以外の形態をとるものとしては，そ れらよりやや大型で不規則な形態を示し，内部に ラメラ状構造物を有するものがある。さらに大き いもので内容が比較的電子密度が均質なものがあ る。また複雑な構造を示すものがあり，1例では あるが粗面小胞体を取り囲んだものも認められ た。 multivesicular body もときどき見られるが, このものの形成過程は峡部細胞において追及でき た。

これらライソゾームの形態形成に関しては NOVIKOFF らの GERL による形成説があるが, 著 者の所見では明らかでない。DE DUVE・WATTI$\operatorname{AUX}(1965)^{76)}$ によるとライソゾームの機能を heterophagy, autophagy の 2 種に分けているが, 唾 液腺では phagocytosis は認められないし，ライ ソゾームの形態からも autophagy 系のものと推 測される。

\section{5. 細胞間の結合}

終末細胞間にはしばしば 細胞間分泌細管が形成 されているが， 終末細胞と峡部細胞との間にもこ のような像が認められる。細胞間の接着装置とし ては腺腔側に FARQUHAR ・ PALARDE (1963) ${ }^{71}$ の junctional complex が，それより深部には嵌合が 形成される。RUTBERG(1961) ${ }^{25)}$ はマウスの耳下 腺終末細胞間に, TANDLER(1962) ${ }^{47}$ はヒトの顎下 腺漿液細胞に，吉村・入江(1961) ${ }^{399}$ はイヌの顎下 腺粘液細胞間に細胞間隙があるとしているが，八 ムスターにおいてはそのような像は認められな い。ただし未発表であるが著者はネコの耳下腺に は著明な間隙があるのを観察している。

細胞基底の膜陥入はハムスターで SHACKLEFORD・WILBORN (1968) ${ }^{18)}$ が指摘しているように， 著者もほとんどこれを認めない。しかしときどき 筋上皮細胞の接着面と 終末細胞基底の隣接部とに 嵌合または基底陥入とおもわれるような像が 認め られる程度であるが，イヌおよびヒトの頡下腺で は著明な基底陥入により, 絨毛様突起のような形 態を示すとされている。

6. 液. 胞

液胞は，その出現頻度は低、。その内容は電子 密度が低く，周囲には比較的電子密度の高い細胞 
質が被膜状をなして, 細胞小器官が直接接するの を妨げるような関係を示している。しかしときに 分泌顆粒拈よび電子密度の低い細胞質の一部が液 胞内に突入するような形態も認められる (図 7)。 液胞の形成については COVELL (1928) ${ }^{78)}, \mathrm{HIRSCH}$ $(1931)^{791}$ ，RISE (1935) ${ }^{80)}$ の光顕的研究がある。か れらは膵細胞を pilocarpine による刺激下で観察 し, COVELL は zymogen 顆粒の液化によると し, RIES と HIRSCH とは zymogen 顆粒の coalescence によって形成されるとしている。さらに HIRSCH は zymogen 顆粒の solution と細胞の水 分吸収による water vacuole との 2 種の液胞を 区別している。電䫓的には PALADE $(1959)^{81)}$ が膵 細胞における液胞は zymogen 顆粒の coalescence によって形成されるとし，PARKS(1962) ${ }^{9)}$ はマウ スおよびラットの耳下腺終末細胞では，ある小液 胞は分泌顆粒の膨化によるものであり，ある液胞 は分泌顆粒からでなく，膜性構造に由来すること を観察し，この点に関する限りでは光顕的研究の 結果を支持している。しかし電顕的には分泌顆粒 および液胞がそのままの状態で放出されるとした 先人達の所見には同意しがたく，分泌は両方とも に内容物のみが放出されるのであると PARKS は 述べている。

PARKS はまた24時間の絶食後に摂食させ 30 分 経たものおよび pilocarpine 注射15分後の耳下腺 終末細胞を観察して，液胞に次の 3 型があること を示している。すなわち(1) 分泌顆粒起源のも の，(2)不規則な形態を示し，ゴルジ囊または同 じような構造物の膨化と思われるもの，(3)電子 密度の低、細胞質の隆起が液胞内にふくれ出るも のである。著者は PARKS の (2) とするものの由 来を追及できる所見を得ていないが，同氏の（3) とするものにさらに分泌顆粒がはいり込むような 像(図 7)を得ているので，液胞の形成には分泌顆 粒の関与むあるであろうと考えられる。

次に液胞周囲における 細胞質の被膜様の細胞質 部については PARKS も記载しているが,このよ うな構造は液胞が 細胞頂部に分布するものほど明 瞭である。しかし液胞内に分泌顆粒あるいは細胞 質の一部が突入するような 像を示すものでは明ら
かでない。このようなことから，この被膜様構造 物は液胞が細胞頂部に移動するに従って 形成され るもののようで，なんらかの意義があると推測さ れる。

一般に成書によれば 生理学的には水分の放出は おもに峡部細胞で 行なわれるとしている(河村) ${ }^{821}$ が，液胞の内容は電子密度が低く，水分を多く含 むものと考えられるので，終末部からも水分の放 出がなされるものと思われる。

7. 紱毛様突起 (microvilli)内の細線維

絨毛様突起に細線維がはいって支持の働きをす ることは，小腸上皮細胞において一般によく知ら れている。その他ウシの肝毛細胆管上皮にも細線 維があることが報告されている(WOOD 1961) ${ }^{83) 。 ~}$ 唾液腺においても SHACKLDFORD・WILBORN $(1969)^{59}$ がウシの 耳下腺の終末細胞とオポッサム の頻下腺の終末細胞の絨毛様突起 にこのようなも のを認めている。このらちオポッサムにおける細 線維 は一端が デスモジームにはいるとしている が，これは小腸上皮細胞のものが terminal web を形成する細線維で，一端が intermediate junction に接すとされているのと異なる。著者の場合 にはやや不確かではあるが 突起の内部に細線維ら しきものが認められた。

\section{B 映部細胞}

峡部細胞は他の動物 の 唾液腺におけると同様 に，終末細胞に比較して小型であるが，八ムスタ 一の耳下腺のものでは 細胞小器官の発達は終末細 胞とほぼ同様に著明である。分泌顆粒の含有量が 多く，分泌機能が旺盛である。

1. 分泌顆粒の形態

形態は 3 種に分類できる。すなわちその内容の 電子密度が低く均質なもの，著しく高いものとが 区別され，その中間型として電子密度の低い内容 物中に密度の高、塊状物を含有するものがある。 中間型とするものは固定処理による人工産物のよ うに見えるが，分泌顆粒が細胞外に放出され，ま たは類結晶化する過程が追及できるので, 細胞の 機能"によよる 濃縮現象ではないかと考えられる。 SHACKLEFORD・WILBORN(1968) ${ }^{18)}$ はハムスター で，終末細胞の顆粒より高い電子密度の顆粒を記 
載している。

PARKS(1962) ${ }^{9)}$ によればラットにおける顆粒も 電子密度が高いものと低いものとの 2 種が認めら れ，それらは均質であるようにいわれている。な お同氏はラットでは 終末細胞の分泌顆粒は不均質 な内容を示すが, 峡部のものは均質であるとして いる。しかしハムスターのものは中間型のものが 不均質で, ラットの所見とは一致しない。光顕切 片での PAS 反応および toluidine blue 染色によ る染色性は, 峡部細胞の顆粒のほうが 終末細胞の 顆粒より強い反応を示し, 電子密度と染色に対す る反応とが一致する。このようなことは終末細胞 の顆粒でも同様である。すなわち終末細胞の顆粒 第 I・II型のものは比較的電子密度が低く, 染色 性も弱い。第而型のものは顆粒中心部に 電子密度 の高い部分を有するが，一方 PAS 反応および toluidine blue 染色で中心が強陽性の反応を示す顆 粒像がしばしば認められるので，このようなもの は第而型のものに一致するものと推測される。

顆粒の放出過程は終末細胞のものと異なり，さ らに腺腔および管腔に放出された放出物の形態 から見て，その内容物 も異なるものと考える。

SHACKLEFORD・WILBORN (1968) ${ }^{18)}$ はこれらにつ いては記載していない。光顕的所見として市川 '(1961) ${ }^{841}$ は八ムスターの耳下腺介在部の項で，核 上部とくに遊離縁にそって，滆漫性に PAS 強陽 性を示す均質無構造の部分が認められるが，遊離 渌でこれらが放出されると考えられるような 積極 的な意味のある所見は認められないとしている。 、分泌顆粒の形成について見ると，ゴルジ装置の 形態および発達も終末細胞と同様であり，同じ形 式で形成されるものと考えられる。

分泌顆粒は 3 種とも常にその内容が線維状化す る像を呈するが，これと同様のものがときどきゴ ルジ装置内方の謽内に含有されているのが認めら れることがある。これによって分泌顆粒は 3 種と もゴルジ装置由来であることが明らかである。

2. ライソゾーム

その1形態である multivesicular body につい ては SOTELO ・ PORTER (1959) ${ }^{70}$ が初めて報告し, その後これらの由来についてはゴルジ装置由来の
The Forming Process of Multivesicular Bodies
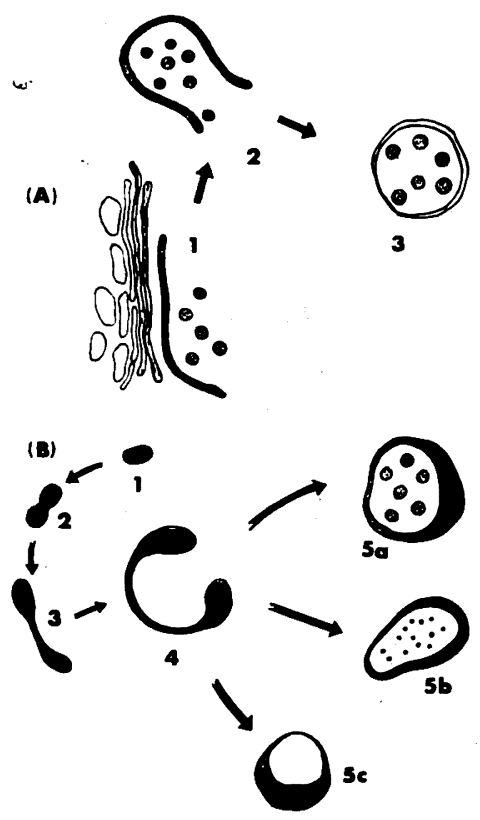

模型図 1 multiuesicular body の形成過程ならび に dense body の分化

A はゴルジ哓がゴルジ小胞をとり囲み形成されるも ので，数字はその過程を示す。

B は dense body の分化 $(1 \rightarrow 2 \rightarrow 3 \rightarrow 4 \rightarrow 5)$ を示 し, 4 の長く伸びた亜鈴状の dense body がゴルジ 小胞を内部にとり囲んで 5 a のような multivesicular body の形態をなすことを示す。

もの (BRUNI ・ PORTER 1965) ${ }^{85)}$ ，細胞膜由来で phagocytotic vesicle を含むもの(ROSENBLUTH • WISSIG 1964) ${ }^{86)}$ ， あるいは核膜由来のもの (KILANSKI・JASINSKI 1970) ${ }^{87)}$ などが報告されている。 著者の所見では明らかにゴルジ装置由来のもので あり，その形成過程と思われる 所見が得られた。 その過程は模型図 1 で示すようにゴルジ装置内方 の最内層のゴルジ毫の一端の屈曲が増して C 字形 をなし，その内にゴルジ小胞を入れる(図23，24）。 このゴルジ豪の両端が瘉着することによって, multivesicular body の形成が完了するものと考 える。この multivesicular body の形成に関与す るゴルジ唯は，他のゴルジ衰とは少し離れた部位 を占め, 電子密度の高い内容を満す。一方 dense body のいろいろな形態の移行的所見が認められ 
るが，模型図 1 のようにして 形態的分化が 起こ るものと推測される。それらのうちには環状の dense body の内部に小胞を有し, multivesicular body と同様の形態を示すものが見られる(図 7) が,これは multivesicular body の1種で明らか に dense body 由来のものと考えられる。しかし てこのようなものの形成される過程をたどって見 ると, まず dense body が比較的ゴルジ装置の近 くに分布することが観察されるが，そのうち亜鈴 状をなした dense body の両端が癒着, 融合すれ ば上述のような形態のものができる。このように multivesicular body の膜成分の由来はゴルジ震 によるものと, 亜鈴状の dense body によるもの との 2 系統のものが存在し, 内部の小胞はゴルジ 小胞由来のものであると考える。

3. 終末細胞の補充

$\operatorname{SICHER}(1966)^{88)}$ は峡部が 分泌細胞を含むとき はいつでも，その部分と終末部との間の移行は漸 進的で, 峡部の終末部に近い部分は, 基底が好塩性 で, 頂部に分泌顆粒を有する小型の終末細胞に類 似した細胞よりなり，遠位部（線条部に近い峡部） は分泌性のない細胞によってできていると記載し ている。また PROVENZA (1964) ${ }^{89)}$ は，峡部細胞 の原形質が少ないことは 細胞の未分化な状態を示 すもので, 多くの研究者はこの細胞は破壊された り，傷ついたりした 終末細胞の補充源であるとの 見解をもっていると述べている。このように終末 細胞の補充については, 峡部細胞の分化の程度が 低く，これが分化して 終末細胞になるという説が 一般に受け入れられている。しかるにハムスター の耳下腺峡部細胞は分泌機能ならびに 細胞小器官 の発達の程度から見て，終末細胞と同等かまたは それ以上の機能を営んでいる像を示し，これが未 分化細胞であるとは考えることができない。なお 著者は峡部細胞が終末細胞に分化すると思われる 像を観察することができなかったが，峡部と終末 部との移行部には終末細胞に混じって峡部細胞の 存在する像を見ることは珍しくない。

次に SICHER が記載しているように，峡部の遠 位部においては 無顆粒細胞の存在が認められる が; その出現数はごく少ない。この無顆粓細胞は
明らかに分泌機能を有する近位部の細胞に比較し て小型で, 細胞質も少なく, 細胞小器官の量がわ ずかである。また線条部に続く遠位部にある峡部 細胞のなかには，線条部細胞と同様な小型の分泌 顆粒を有するものが見られることから， 終末細胞 への分化よりもむしろ 線条部細胞への分化が想像 される。

著者はラットの耳下腺では 終末細胞がときどき 2 核を有する例に遭遇している (未発表)。KURTZ (1964) ${ }^{12)}$ も同材料で同じ所見を図示しているの で, この場合本細胞の無系分裂による補充の可能 性が考えられる。しかしハムスターではこのよう なものは見られなかった。しかるにハムスター終 末部における 基底明調細胞では，1例ではあるが 核および細胞体の無糸分裂様像が見られた。なお FERNER ・ GANSLER (1961) ${ }^{90)}$ は線条部基底明調細 胞の無采分裂様形態について述へ，この細胞が線 条部細胞の補充源の一つになると考えている。一 方この種の細胞から終末細胞に分化していくので はないかと考えられる移行像を追及できた（図11， 12, 13) ので, この細胞を終末細胞の補充源の一 つと考えることは可能ではないかと思われる。

\section{C 線条部細胞}

線条部細胞には基底膜陥入を有する 明調細胞と 細胞質の電子密度の高い暗調細胞および 基底明調 細胞の 3 種が区別される。

線条部の大部分は明調細胞によって 構成され, 暗調細胞はときどきそれらの 細胞間に介在するの が見られる。基底細胞はごく少数と思われ, 著者 は 1 例その存在を認めたのみである。WILBORN・ SHACKLEFORD (1969) ${ }^{63)}$ がオポッサムの䫟下腺線 条部および導管部で暗調細胞, 明調細胞および基 底細胞 I， II を区別している。またかれら シの耳下腺線条部で明調細胞と暗調細胞とが 区別 されるとしている。TAMARIN・SREEBNY $(1965)^{13)}$ はラットの頻下腺導管部で暗調細胞, 基底細胞が 区別されるとしている。著者のハムスターの耳下 腺における所見では，WILBORN・SHACKLEFORD の示す明調細胞, 暗調細胞および基底細胞 I型の ものとほぼ一致する。かれらは上記の各種細胞間 には間隙を有し, その間隙に䋘毛様突起を出す像 
を観察しているが，ハムスターにおいては終末細 胞，峡部細胞および線条部細胞とも著明な細胞間 隙を示さなかった。

\section{1. 明調細胞}

明調細胞では核上部にゴルジ装置，細胞頂部に 小胞状の分泌顆粒が認められるが，峡部細胞およ び終末細胞におけるように、 ゴルジ装置から分泌 顆粒が形成されるような像を認めることができな かった。また RUTBERG (1961) ${ }^{25)}$ はマウスで, SCOTT・PEASE(1959) ${ }^{4}$ はラットで，いずれもそ の線条部細胞のゴルジ装置は分泌顆粒形成に関与 しないと述べている。ゴルジ装置の形態も終末細 胞, 峡部細胞のものと異なり，扁平なゴルジ震が 層板構造をなすような像は認められず, 内腔がふ くらんだ空胞状のものが数個集まっている 形態を 呈する。ゴルジ装置の数も少なく, ゴルジ野の形 成は見られない。以上のように線条部明調細胞に 見られる分泌顆粒の形成由来に関しては明らかで なく, 今後の研究に期待される。なお分泌顆粒と zonula adhaerens(intermediate junction) に一端 が付着する線維束およびアポクリン分泌様分泌と の関係については後述する。

\section{2. ライソゾーム}

ライソゾームがしばしば分布するのが見られる が, 大部分は終末細胞および峡部細胞におけると 同様の類似小体, すなわち dense body であり, 比 較的大きい形態のものが観察される。TAMARIN・ SERRBNY $(1965)^{13)}$ は dense body または composite body の出現は, 蛋白質吸収および細胞内消 化の機能を有することを示すものであるという STRAUS (1964) ${ }^{91)}$ の説を記述している。

\section{3. 基底陥入}

細胞基底部には RHODIN(1954) ${ }^{92)}$ が初めてマウ ス腎尿細管の細胞で示したような, 著明な基底細 胞膜陥入が見られ，他の諸種のホニュウ動物唾液 腺で報告されているものと変わりがない。隣接す るこの種の細胞の側面にデスモゾームが見れ，さ らに基底細胞膜陥入によって区画された細胞質部 分に明暗両部が認められる(図31)。

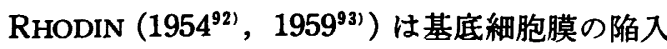
性接細胞の突起の指状嵌合であると述べている
が，著者の上記の像はこれに一致するもので，明 暗部は隣接細胞突起の一部が混在した像であると 解される。このような形態は他の多くの先人の研 究成果にも一致する。俩入膜間には糸粒体が豊富 に存在し, 陥入膜と糸粒体が密接な関係を有する ことを印象つける。糸粒体の形態は，TANDLER $(1963)^{\text {(8) }}$ によればヒトの影下腺線条部では桿状で あるとしているが，八ムスターでは球状のものが 多く, 桿状のものは比較的少なくておもに基底膜 に接する層に存在する。

基底陥入膜の一端に連鎖状にならぶ小胞がとき どき見られる(図32)。この連鎖状小胞はTANDLER $(1963)^{48)}$ 女観察し, PAPPAS - SMELSER (1958) ${ }^{94}$ が網膜細胞で観察したものと同一であるとしてい る。小胞㴼入膜の崩壊によるともいわれ（PAPPAS・SMELSER 1958), 出芽法により形成される (TANDLER 1963) という説もある。著者の像も Tandler と同様であるが，それが上記二つの様式 のうちどの方法によって由来するのか明らかでな w。

次に細胞基底部に数個の大きな液胞状のものが 出現することがある。このようなものには糸粒体 は見られず，電子密度が低く，一見したところで は何か細胞外の構造物のように見えるが，詳しく 観察するとこれらのものの現われる領域は明らか に細胞膜に包まれ，少数ながらも遊離のリボゾー ムが散在している。なお細胞膜は他の細胞と同様 の介在層を介して基底膜に接するが，この液胞状 物の形成は隣接する細胞数個に同時に現われるも のでハムスターだけでなく，ツパイの耳下腺と影 下腺とでもときに見られる。

$\operatorname{PEASE}(1956)^{95)}$ は基底宿入に関して，これはイ オン，水分の運搬にあずかるものであろうと推測 し, TANDLER $(1963)^{48)}$ もこれに同意して, 連鎖状 小胞の出現は膜活性を意味するものであろうとし ている。著者も上記の像および連鎖状小胞の出現 は膜機能の所産と考える。

このような明調細胞の基底細胞膜の機能に対し て, 一方細胞頂部でも分泌顆粒, アポクリン分泌 様形態が認められるので，明らかにこの細胞は分 泌機能を有すると考えられる。しかここの細胞は 
山元の述べるような形態において 吸収細胞様の形 態を有するといえる。山元 $(1970)^{96)}$ は遊離表面の 絨毛様突起, 細胞側面の嵌合, 細胞基底の細胞膜 の陥入, 紱毛様突起直下の小胞, dense body, 遊 離縁直下の中心子，基底細胞膜と系粒体の特異な 分布などをあげて吸収細胞の特徵としているが， 線条部明調細胞にこのような特徽のおのおのを認 めることができる。また TAMARIN・SREEBNY $(1965)^{13)}$ はラットの頇下腺線条部で 細胞頂部に小 胞と細胞膜とが連続して pinocytotic activity の あることを支持する像を記載している。また緒方 $(1939)^{97)}$ は線条部における parotin の再吸収性を 実験的に証明して (光顕的に)，吸收説をたててい る。さらにこれに関して電顕的にも関 $\left(1959^{3)}\right.$, $\left.1960^{38)}, 1961^{71}\right)$, 滝沢ら $(1957)^{98)}$, 野口 $(1968)^{32)}$ 等の研究があり，吸収機能のあることを考えてい る。著者の所見では細胞頂部に小胞は認められる が, TAMARIN・SREEBNY のような pinocytotic vesicle を直接見ることはできなかった。しかし 上述した細胞の諸形態から推測して何か吸収機能 をもっているのではないかと推測されるけれども 明らかな像を認めることはできなかった。

\section{4. 暗調細胞}

暗調細胞は耳下腺においてはウシにのみその報 告があるが，オポッサムの顎下腺のものと形態が よく似ている。暗調細胞は一般に人工産物による ものであろうという考えがある(ICHIKAWA， 1967) ${ }^{999}$ が，著者の得たものは特殊な形態をもって いることから，単なる人工産物によるものではな く，明調細胞と区別されるべきものと考える。こ の暗調細胞は明調細胞と同じく zonula adhaerens に付着する線維束をもっていると同時に，峡部細 胞のものとよく似た 分泌顆粒を有することがある （図35）。以上のことからこの細胞は峡部細胞が明 調細胞へ分化する途中の形態の細胞であるか， あ るいは両種細胞の性状を兼ね備えた 細胞のようで ある。

\section{5. 基底明調細胞}

PARKS (1961) ${ }^{6)}$ によればマウスの耳下腺の峡部 と終末部の 基底膜と 上皮細胞との 間には 明調細 胞があるが，このものは終末部では分泌細胞でな
く，神経でも，筋細胞でもなく，筋上皮細胞，峡 部細胞または終末細胞へ移行する細胞であろうと いう。PRovenZA (1964) ${ }^{89}$ は峡部には籠細胞, 基 底細胞が見えるとし，WILBORN・SHACKLEFORD $(1969)^{63)}$ はオポッサムの䅡下腺の線条部および導 管部で 2 種の基底細胞を区別している。

このように諸氏によって 基底細胞または明調細 胞と称せられるものは終末部, 峡部, 線条部およ び導管部の各部位に存在することが 報告されてい るが，それらに共通する点は未分化な形態を示す ことである。なお基底細胞または明調細胞といわ れるものは同一物と考えられるので，著者はこれ を基底明調細胞とした。著者は終末部の基底明調 細胞に FERNER・GANSLER と同じような分裂像 と思われるものを認めたが，さらにこれらの細胞 の細胞質が少量であることから未分化なものと考 える。このようなものにしだいに粗面小胞体が出 現, 増大し, 系粒体も増加し, ゴルジ装置が出現 することなどに伴って細胞体が大きくなり，終末 細胞基底部に位置していたものが 細胞間に深くは いり込み, 細胞頂部を腺腔に近つ゚けるというよう な細胞分化の過程が追及できた。

以上の事実に基づいてこの細胞を 終末細胞の補 充細胞に相当するものではないかと考える。また 峡部および線条部に認められたものは，その分化 過程を追及することはできなかったが終末部にお けるものと同様な意義を有するものと推測する。

\section{D 耳下腺終末部粘液細胞}

この細胞は終末細胞(漿液細胞) とは 混在せず, この種の細胞のみからなる終末部を形成して, 耳 下腺峡部に連なり, 峡部細胞とはデスモジーム, 嵌 合などによって接することが認められた(図15)。 この細胞は (図14，15)終末細胞より大きく，分泌 顆粒は電子密度の低、均質な内容を有し, 平均2.6 $\mu$ 程度で大きい。また粗面小胞体の内腔が広がり， うちに比較的電子密度の高、物質を含むこと, さ らにゴルジ装置のゴルジ震内の電子密度が内方よ りも外方のものが高く， 終末細胞および峡部細胞 におけるものと反対であるなどの特徴がある。な おこの種の細胞の細胞は耳下腺では常在性のもの ではなく，電顕的には 1 個体にだけ見られたが, 
光䫓的には他の個体についても見つかっているの で，それほどまれなものでもないようである。

この粘液細胞 $\left(\mathrm{MC}_{1}\right)$ の形態を舌下腺の粘液細胞 $\left(\mathrm{MC}_{2}\right)$ のそれと比較して見ると，その粗面小胞体 が扁平で，䧶内の電子密度が低い点ではむしろ耳 下腺終末細胞と峡部細胞とにおけるものに似てい る。また $\left(\mathrm{MC}_{2}\right)$ ではゴルジ野を形成する像はあま り認められないが，( $\left(\mathrm{MC}_{1}\right)$ ではしばしば見られ る。さらに糸粒体は $\left(\mathrm{MC}_{1}\right)$ では $\left(\mathrm{MC}_{2}\right)$ よりもかな り小さいなど以上の三つの特徴から $\left(\mathrm{MC}_{1}\right)$ は舌 下腺のものと明らかに相違する。一方, $\left(\mathrm{MC}_{1}\right)$ 細胞はあらゆる点で眼窩外涙腺（側頭筋上にある 純粘液腺, exorbital lacrimal gl.) 細胞に似てお り 眼窩外涙腺の細胞が混在したかのような感じを いだかせる。

漿液性終末部に粘液細胞の出現することに関し ては, 市川 $(1961)^{84)}$ が觢歯類の顥下腺の光顕的研 究に際して， 八ムスターにこの種の細胞の出現す ることを報告しているが，これは大舌腺終末細胞 と一致した特徴を有し，また顎下腺終末細胞とは endocomplex を形成しないことなどから，発生途 上に大舌下腺原基の迷入混在したものであろうと している。加藤(1957) ${ }^{1001}$ はイヌの耳下腺において 粘液終末部が常在性であるかのような記載をして いる。著者ら $(1969)^{101)}$ はネコ,ハムスター, モルモ ットの耳下腺において，この種のものの出現する ことを報告したが，イヌでは必ずしも常在性とは 限らないもののようで，十数例の観察ではそのよ うなものに遭遇していない。またこの種の細胞は mucicarmine, PAS に強陽性を示し，強酸に対す る反応も陽性に現われる。さらに著者はネコ耳下 腺終末部粘液細胞を電顕的に観察しているが，こ れらの細胞はすべて市川が報告したとおり，終末 細胞とは endocomplex を形成していない。この ものの由来については，耳下腺の場合市川の考え 方では説明できない。またハムスターの場合, 眼 窩外涙腺とこの粘液細胞との類似性 がきわめて高 く，その迷入を思わせるが，ネコ，モルモットで は眼㸗外涙腺に相当するものがないにもかかわら ず，耳下腺にかなり多くの 粘液性終末部が出現す ることは，以上の考えでは説明できない。

\section{E 筋上皮細胞}

筋上皮細胞の分布は八ムスターの耳下腺では終 末部と峡部とにのみ見られ，他の部分には存在し ない。TAMARIN(1966) ${ }^{14)}$ はラットの額下腺に存 在する筋上皮細胞についての詳細な報告をしてい るが，その分布は峡部，終末部で見られ，他の部 分では見られないとしている。さらにこの細胞は 終末部の $12 \%$ ，峡部の $40 \%$ ，また 小葉の実 質細胞の $9 \%$ を占めているとしている。PARKS $(1961)^{6)}$ は Wister 系ラットの耳下腺では，終末 部と峡部とに筋上皮細胞が存在するとしている。 しかし SCOTT・PEASE(1959)" はラットの舌下腺 および䫓下腺の終末部においてはこの細胞の分布 が見られるが，耳下腺終末部には存在しないとし ている。

管上皮細胞の機能として，収縮によって腺細胞 を圧迫する作用が考えられているが，この作用に ついて吉村ら(1961) ${ }^{39}$ はイヌの顎下腺で pilocarpine 注射後, 粘液細胞間の間隙が増大し, 筋上 皮細胞が 収縮することを示している。著者の所 見では分泌途上の細胞に接する筋上皮細胞および 細胞間隙などの 変化は，他の 細胞との 比較にお いて認められなかったし，同様に藤田ら $(1964)^{41}$. もイヌ䪽下腺で副交感神経刺激時の細胞でも変化 が認められなかったとしており，直接分泌物排出 に関与するか否か, 著者の所見では明らかでない。

\section{F 陕部細胞における類結晶 (crystalloid)}

唾液腺における類結晶の出現については次のよ うな報告がある。1）SCOTT・PEASE (1964) ${ }^{10)}$ が ラットの耳下腺終末細胞において，2) TANDLER $(1965)^{50}$ がヒトの顎下腺線条部管腔内において, 3） LUZZATTO et al. (1968) ${ }^{17)}$ がラットの顎下腺 終末細胞において，4）HARD (1970) ${ }^{20)}$ がラット のエブネル 氏腺腺細胞において 報告している。 HARD のは腺細胞の dense body 内に結晶様構造 を認めての記載であり，これはイヌの膵細胞にお いて WATARI et al. $(1968)^{102}$ が, ライソゾーム によって形成されたとして示した 類結晶と同じよ うな形成様式によるものと思われる。著者も終末 細胞のライソゾーム中に, WATARI et al.の示し た種々の類結晶の一つに似たものを認めた。TAN- 
The crystalloid forming process of the substace in the secretory granules in the intercalated duct cell

1

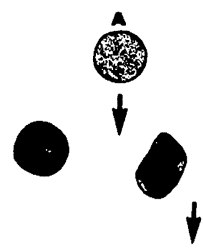

3

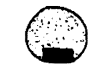

4

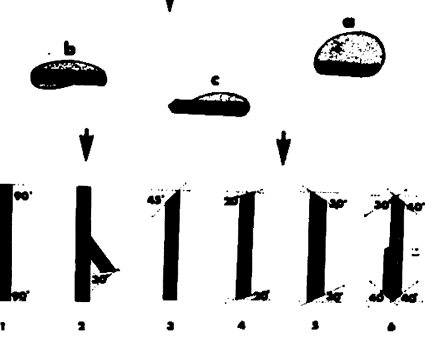

模型図 2 峡部細胞における分泌顆粒内容の類結化 の過程。

1.の A - B は分泌顆粒の 2 型を示す。2. は顆粒内 容の浱縮。3.は穠縮されたものの内に類結晶の核 ができることを示す。4. は類結晶の成長を示し， $\mathrm{a} \rightarrow \mathrm{b} \rightarrow \mathrm{c}$ の順に顆粒成分が減少し類結晶が大きく なる。5. は類結晶の種々の形態を示し, 数字は面 角を示す。

DLER の類結晶は管腔内のものであって一般に細 胞内においての報告であるのと比べて趣きを異に する。なおその類結晶は dentine のアパタイト結 晶に類似するとしている。LUZZATTO et al.のも のは明らかに分泌顆粒内成分が 結晶化したもので あるが，その形態は著者のもの異なることが確か である。SCOTT・PEASE の終末細胞内で認められ た類結晶と，著者の峡部で認めたものとは形態的 に類似する。SCOTT・PEASE は分泌機能を実験的 に高めたときの細胞変化を研究した際にこの類結 晶を認め，その形態を dense rod と表現したが， それらは層板構造をなして配列する 粗面小胞体間 に存在する像を示している。しかしそのような類 結晶に発達するまでの過程の像は示されていな い。著者は類結晶の形成過程を追及するに足りる いろいろの像を得ることができたので以下これに ついて詳述する。

模型図 2 に示すように 形成過程を 4 段階に分け
た。類結晶は明らかに分必顆粒に由来するもの で，その顆粒内容物の結晶化ということができ る。第 1 段階 : 分泌顆粒には電子密度が高いもの （B）と低いもの(A) との 2 種を区別しているが, 両者ではこの段階で内容物が濃縮化され，顆粒の 外形も少し変化するのもある。第 2,3 段階 : (A) 顆粒の一端に濃縮し結晶化された物質の一部が存 在するものが現われる。このような状態のものが 完成された類結晶となるるための結晶成長の核にな るものと推測される。第 1 段階として示した顆粒 の多くは，電子密度の高い(B)顆粒が濃縮化され てできたものであり，このような電子密度の高い 顆粒は結晶化されにくいようである。第 4 段階 : 核となった結晶の成長過程を示するので, $\mathrm{a} \rightarrow \mathrm{b} \rightarrow \mathrm{c}$ の順に結晶が成長する。結晶成長には顆粒内成分 が関与し, 成長が進むにつれてそれは減少し，そ れとともに顆粒の囊が小さくなる。顆粒の限界膜 は, $\mathrm{a} \rightarrow \mathrm{b} \rightarrow \mathrm{c}$ の過程で示すように結晶化が進み, 結晶化してない成分が減少するに従い，消失する ように見られるが, 結晶面に密着しているものと 推測される。

SCOTT・PEASE は類結晶の形成には蛋白質を 産生する粗面小胞体が関係するとし, Palade がモ ルモットの膵細胞では zymogen 顆粒形成がすで に粗面小胞体内で行なわれるとしている知見に基 ゔいて，かれらの見ている慗状粗面小胞体の間に 出現する類結晶も, それと同様に小胞体内で形成 されると考え, 分泌顆粒の変形体様のものとみな し,さらにこれは lipoprotein であると記載して いる。しかし著者の得た類結晶は, ゴルジ装置を 経由して形成された 分泌顆粒内に現われるもので あり, PAS 染色に対して強い陽性を示すことか ら, 明らかに多糖類成分を含む glycoprotein と考 えられ, SCOTT・PEASE のものとは形成様式も 成分も異なるものである。唾液腺以外のものにつ いて報告されている類結晶の由来については多く の可能性が示されている。すなわち FAWCETT $(1966)^{103)}$ によれば類結晶は細胞のあらゆる成分 中に出現するもので，たとえば核，系粒体，粗面 小胞体ゴルジ装值および分泌顆粒中に封入され て，あるいは細胞基質内に遊離して認められ，こ 
の成分は一般に蛋白質性であるとしている。

類結晶の機能的意義について, HAMITON et al. $(1966)^{101)}$ はサンショウウオの肝細胞形質内の 類結晶が季節的に消長することを認め，食物の少 ない季節に対する栄養分の貯蔵と考えている。ま た柴田 (1967) ${ }^{105)}$ もマウス膵細胞形質内の 類結晶 については栄美分貯蔵の一つの型としている。著 者の見た類結晶は前述のとおり，顆粒そのものが 類結晶化したもので, このようなものは 1 個の細 胞内に 1 ないし数個見られる場合がある。その出 現の意義については断言できないが，排出機能の 低下によって顆粒成分の濃縮が起こり，そのよう な形態の出現をきたすのではあるまいか。すなわ ち類結晶は貯蔵的なものではなく，(A)，(B)顆 粒と同じょうに，比較的短時間で崩壊して細胞外 に放出されるであろう。

\section{G 分泌顆粒の放出}

\section{1. 終末細胞}

分泌顆粒には, 全体が明るいもの，周辺部の一 部にやや電子密度の高い部分を有するもの，顆粒 中心部に電子密度の高い部分を有するもの等があ り, それらの関係は別種のものではなく, 内容的 に移行型が見られ，同一系統のものである。これ らの顆粒中, 全体が明るい内容からなる顆粒間に はしばしば融合が認められるので，分必顆粒の内 容物は比較的流動性に富むと考えられる。下垂体 細胞において 分泌顆粒が細胞外一放出された後も 球状形態を保っている像が示されており（黒住 1968) ${ }^{106)}$ ， 細胞外への放出直後ではまだ顆粒はゲ ル状をなしていて形がくずれないものと考えられ る。このような形態はヒ卜䫓下腺漿液性細胞の分 泌顆粒においても認められている (SATO et al. 1966) ${ }^{52)}$ 。すなわちこの分泌顆粒は一般に中央に電 子密度の高い輪郭のはっきりした球状の芯 (core) を有し，周囲は比較的明るい物質からなる 卵形の 顆粒であり，分泌顆粒は黒住のIV型(emiocytosis) 107)で放出されるが，腺腔および細胞間分泌細管内 に球状の芯の部分がそのまま認められる。この形

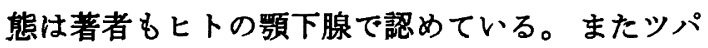
イの䫟下腺漿液細胞の顆粒もヒトの颚下腺のそれ と同様に芯を有し，その芯の部分が腺腔および細
胞間分泌細管に認められた (峯田1970) ${ }^{108)}$ 。ハムス ターの耳下腺ではこのような形態のものが腺腔な どには認められないし，また彗歯類のものでその ような形態のものが腺腔および 分泌細管には認ら めれていない。それゆえ顆粒の内容物は上記のも のとは異なる性状のものと考えられる。

分泌顆粒はいわゆる 黒住の放出機序の分類にお けるIV型 (emiocytosis) ${ }^{107}$ に属するものと考えら れるが, ときに細胞膜に接した後, 細胞膜が腺腔 に向って突出していく像が見られ，これは一見し て microapocrine (黑住のIII型) ${ }^{107)}$ を思わせる。分 泌顆粒の放出に先だって, しばしば腺腔近くの顆 粒が液胞の内腔に突入する像が見られ，液胞に顆 粒内容物が融合するものと思われる。この液胞も 黒住のIV型によって放出される。

このように終末細胞では 液胞と分泌顆粒の二つ の分泌が見られ，顆粒成分は 2 系統の放出法を有 する。すなわち顆粒自身の放出と液胞を介しての 放出とである。

\section{2. 峡部細胞}

峡部細胞の分泌顆粒の放出様式は emiocytosis

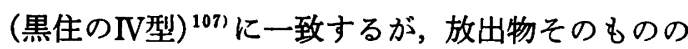
点で異なる。すなわち下垂体, 膵細胞では分泌顆 粒の形成初期または成熟した形のものが，そのま まの状態を有しながら放出されるが，しかしこの 峡部細胞の場合では，分泌顆粒が細胞頂部に移動 するまでに，顆粒形態およびその内容物が変化し て線維状物を含む液胞状になる 点が著しく趣きを 異にしている。その放出過程は模型図 3 に示すと おりである。分泌顆粒にはAに示すように均質な 比較的低い電子密度を有するもの (a ), 電子密度 の非常に高い塊状物によって満されているもの (b)およびそのような成分の比較的少ないもの (c) の 3 型を示しているが，これらはおのおの顆粒内 容物が水分を吸収し，融解またはゾル化すること により，Bで示すような部分的線維化を生じる段 階が見られる。なお顆粒が水分を吸収することの 可能性は，顆粒限界膜がゴルジ装置由来のもの であり，ゴルジ 装置は一般に水分調節にあずか るという知見のあることから理解し得る。この ように線維状化した内容を有する顆粒は球状から 
The excretory process of the secretory granules in the intercalated duct cell

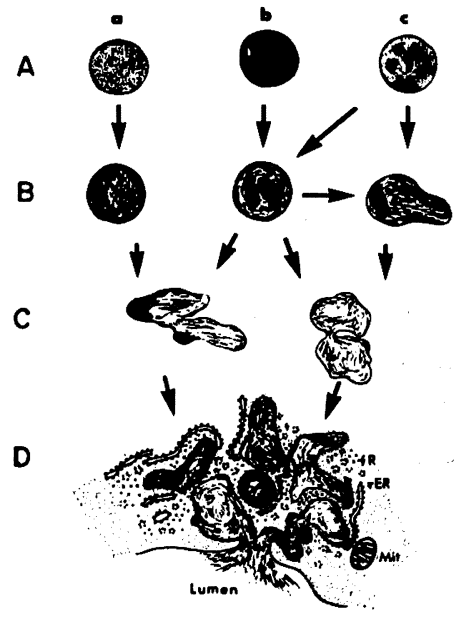

模型図 3 陕部細胞における分泌顆粒の放出過程。 Aの a . b . c は分泌顆粒の形的を示す。 B はAに おける分泌顆粒の内容が部分的に線維状化する段階 を示すもので矢印はその過程を示す。C は分泌顆粒 が液胞状となり, それらが互いに癄着, 融合し大き くなることを示す。 D は放出像を示す。 $\mathrm{fR}$ : 遊離 のリボゾーム, rR: 粗面小胞体, Mit：糸粒体。

その形が変じ，著しいものは液胞状となる。この 液胞のまわりには PARKS $(1962)^{91}$ が認めたよう に，粗面小胞体，遊離のリボゾームなどの細胞小 器官が密接せず， 細胞質の薄層によって被覆され たような状態を呈する。このようなものは細胞頂 部においてさらに著明に見られる。次の段階とし てCではこれらの液胞状をなす顆粒が互いに接し て融合し，大きくなる傾向を示す。さらにDに示 すように細胞頂部の細胞膜に 接し, emiocytosis に従って管腔に放出される。

以上のように $\mathrm{A} \rightarrow \mathrm{B} \rightarrow \mathrm{C} \rightarrow \mathrm{D}$ の過程をとって放 出されるのであるが，このような経過を示す分泌 様式恃異なものではないかと思われる。

3. 線条部明調細胞

線条部明調細胞には第 3.章 E-1 で述べたような 各種の形態が認められたが，小胞状の顆粒の分泌 機序として明らかな管腔への放出像は見られず， （1）この顆粒の出現，増加，減少と，（2）細胞頂 部の bleb または ballooning 化および(3) intermediate junction に付着する゙細線維束の 3 者の
間に密接な関係が認められた。小胞状顆粒につい ては RUTBERG ${ }^{25}$ はマウスで，分泌顆粒というよ りは吸収を明示するものであろうとし，さらに放 出像および管腔内に 分泌顆粒が見られないことか ら，放出前に崩壊されるのではないかともいって いる。bleb 様突起の出現については PARKs ${ }^{\theta 1}$, TAMARIN • SREEBNY ${ }^{13)}$, SHACKLEFORD $\cdot$ WILBO$\mathrm{RN}^{59)}$ ，KURTZ ${ }^{12)}$ も線条部細胞でこれを認め, PA$\mathrm{RKS}^{9}$ は bleb が細胞から分離して唾液の一部にな ると述べている。このようなことから 小胞状顆粒 は放出前に崩壊し, bleb 様突起形成に参加し, ア ポクリン分泌様機序により放出されるのではない かと推測される。

この仮説により，種々の形態を示す細胞を細胞 の機能 およびアポクリン分泌様活動における一 時期のものであるとすると，模型図 4 のような secretory cycle が考えられる。この図により著者 はハムスターの耳下腺線条部細胞の細胞機能を説

The secretory cycle in the striated duct cell

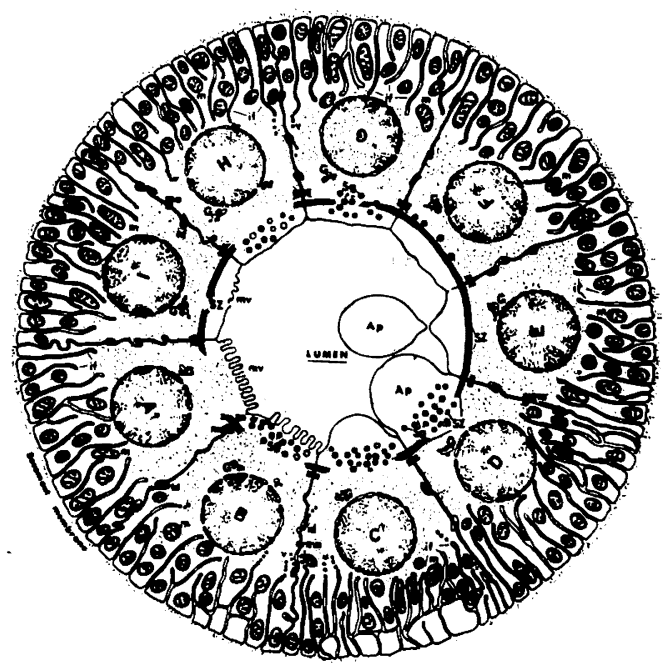

模型図 4 線条部明調細胞の分泌周期の形態 $\mathrm{A} か ゙$ 静止期のもので一周期として, $\mathrm{A} \rightarrow \mathrm{B} \rightarrow \mathrm{CD} \rightarrow$ $\mathrm{E} \rightarrow \mathrm{I} \rightarrow \mathrm{A}$ の過程をとるが, 細胞の機能によっては, $\mathrm{A} \rightarrow \mathrm{B} \rightarrow \mathrm{C} \rightarrow \mathrm{D} \rightarrow \mathrm{E} \rightarrow \mathrm{F} \rightarrow \mathrm{G} \rightarrow \mathrm{H} \rightarrow \mathrm{C} \rightarrow \mathrm{D} \cdots \mathrm{E} \rightarrow$ $\mathrm{A}$ という過程をとる。 $\mathrm{Ga}$ : ゴルジ装置, $\mathrm{m}$ : 手粒体, if : 基底陥入, zo : zonxla occuludens, za : zonula adhaerens, ma : macula adhaerens. sg: 分泌顆粒 sz: 細線維束 (separating zone), mv: “紱毛様突起 Ap : アポクリン分泌様突起。 
明すると，それぞれの実像もこの図とほぼ一致す る結果となる。 A 細胞は細胞分泌機能の静止期に 相当し，細胞頂部に整然と絨毛様突起を有するこ とが特徴である。分泌活動が始まると小胞状の顆 粒が細胞頂部に集積してくる。それらの顆粒の崩 壊, 融解することにより徐々に絨毛様突起の消失 とアポクリン分泌様突起の形成増大が見られる $(\mathrm{B} \rightarrow \mathrm{C} \rightarrow \mathrm{D})($ 図26,27, 28)。

$\mathrm{D}$ 細胞(図27)において，アポクリン分泌様突起 がより増大すると，その基部に intermediate junction (za)に付着する 細線維が伸び，これと同 時に分泌顆粒間に細線維束の新生が行われる。こ の細線維束について KURTZ (1964) ${ }^{12)}$ は bandlike structure と記載し, TAKANO(1969) ${ }^{61)}$ は反 すう動物の唾液腺において発育可良であることを 認め, separating zone という名称を与えている。 また黒住ら (1961) ${ }^{109)}$ はイエウサギの䫟下器官の 細胞におけるアポクリン分泌の像を認め，この場 合もまた突起の基部に現われる 電子密度の高い部 分に demarcation zone という名称を与えてい る。しかし顎下器官におけるものは唾液腺の細線 維束のように著明ではないようであり，著者は以 後 separating zone という名称を採用する。

E 細胞は分泌突起が離する像であるが，この時 期のものは separating zone が細胞頂部を連続し て横切り, 最む著明な像を呈する時期である。そ の後細胞の分泌機能が低下すれば I 細胞（図26） の時期となり, separating zone は中央部付近か ら消失し，細胞頂部には絾毛棣突起の形成が始ま る。しかし分泌顆粒は出現しない。さらに Separating zone の消失が進み 紱毛様突起が 形成され て，A細胞のような形態になり，静止期となる。

一方, E細胞における 分泌物の離出が行なわれ た後，分泌機能が旺盛なものは F 細胞 (図30)のよ うに separating zone 直下に分泌顆粒が集積す る。 separating zone が離断され消失していくに 従い, 分必顆粒は細胞頂部に移動 $L, ~ G$ 細胞（図 29，30）の様相を呈する。

H細胞ではすでに separating zone が消失し， わずかに intermediate junction の部分にだけそ の存在が認められ，分必顆粒は細胞頂部に集積す
る。このような過程を経てきた 細胞頂部には䋐毛 様突起は形成されない。次いで $\mathrm{C}$ 細胞 $\rightarrow \mathrm{D}$ 細胞 $\rightarrow$ $\mathrm{E}$ 細胞のような順序で 形態の変化が行なわれてい く。分泌機能の旺盛な細胞も終局的には 静止期 $\mathrm{A}$ 細胞になるのであるが，その静止期にはいるため. には必らずEから I を経ることが必要である。

線条部明調細胞は以上のような 分泌周期を示す が, これを要約すると， 1 分泌周期として $\mathrm{A}$ 細胞 から $\mathrm{B} \rightarrow \mathrm{C} \rightarrow \mathrm{D} \rightarrow \mathrm{E} \rightarrow \mathrm{I} \rightarrow \mathrm{A}$ 細胞という 経路をと るが，分泌機能が旺盛な場合では， $\mathrm{A}$ 細胞 $\rightarrow \mathrm{B} \rightarrow$ $\mathrm{C} \rightarrow \mathrm{D} \rightarrow \mathrm{E} \rightarrow \mathrm{F} \rightarrow \mathrm{G} \rightarrow \mathrm{H} \rightarrow \mathrm{C} \rightarrow \mathrm{D} \rightarrow \mathrm{E} \rightarrow$ という 過 程をとる。

分泌周期と関連して発達, 衰退を示す separating zone に関しては高野 $(1969)^{611}$ のウシ, ブタ, ヤギ，ヒツジにおける報告, KURTZ(1964) ${ }^{12)}$ のラ ットにおける band-like structure の記載があり, RUTBERG (1961) ${ }^{25)}$ はマウス耳下腺の線条部で形 成可良な separating zone に相当する像を揭載し ている。また著者 ${ }^{108)}$ の観察したツパイ顎下腺線条 部細胞においても separating zone が見られ，少 なくともマウス，ラットの耳下腺とッパイの效下 腺のものでは，八ムスターの耳下腺線条部で見ら れる分泌周期と同様な傾向が認められる。以上の ようなアポクリン分泌様分泌，または細胞質の突 起 (bleb, ballooning)の出現や離断については, 標 本作製上の人工産物の可能性を重視し，このよう な細胞においてはあり得ないと考える 傾向がある が，唾液腺の線条部細胞においては多くの研究者 が bleb, ballooning 様突起を認め, 他の峡部, 終 末部の細胞においてはその報告例がない。このよ うなことは細胞の形態または 細胞の性質による差 異によるものかも知れないが，明らかでなく，そ の究明は今後の研究によらねばならない。

\section{H 終末細胞および線条部細胞における横紋を} 有する細線維束。

横紋を有する 細線維束は終末細胞(図 9 )および 線条部明調細胞(図27)に拈いて各 1 例を得 たのみ であるが，このものは電子密度の高いはっきりと した横紋構造を有し，それらの間隔は等しく800〜

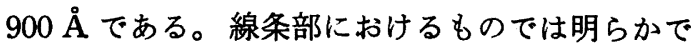
ないが，終末細胞におけるものでは，それらの横 
紋構造の間にさらに $1 \sim 3$ 本のより細い横線が認 められる。このような構造はコラーゲン線維を思 わせるが，コラーゲン線維の横紋は $640 \AA ̊$ 間隔と されており，著者の得た同線維の像からも600 $700 \AA$ という結果が得られており，前述の 2 例の ものに比べると横紋の間隔が小さい。

また線毛が尿細管，甲状腺，膵島 $\beta$ 細胞ならび に腺細胞, 下垂体細胞, 線維芽細胞および笳細胞 で認められており（武田1965） ${ }^{1001}$ ，このものの根 小毛も横紋を有することが知られている。しか しこれは 400 600 ̊̊の間隔とされており（橋本 1968) ${ }^{106)}$, 著者の得たものよりはより小さい。こ のようなことから著者の細線維束はコラーゲン線 維および線毛の根小毛とは明らかに 異なるむので ある。

この細線維束は細胞のトノフィラメントまたは その集束が散在する中に存在し，それと同種のも のと考えられる。しかし著者の知るかぎりではこ のトノフィラメントが横紋を有する線維束を形成 するという報告を見ない。 BRODY $(1960)^{1111}$ がト ノフィラメントの線維間に線維間物質が現われる 像を斑点状構造 (speckled pattern) と称している が，それとは明らかに異なるようである。

\section{I nuclear body}

核内構造物または核内封入体としての nuclear body は De THE et al. (1960) ${ }^{112)}$ にっって初めて 発見された。次いで HINGLARIS et al. (1961) ${ }^{113)}$ の報告があり，WEBER et al. (1963) ${ }^{69)}$ がウシの 種々の実質細胞および精巣間細胞において発見 し, nuclear body という名称を与えた。それ以後 この種の形態のものにはしばしばこの名称が使用 されている。そのほかの核内封入体としては，山 田 (1965) ${ }^{114)}$ が, グリコーゲン，類結晶，脂質顆 粒，一モグロビン等を記載しており，ビールス封 入体(GRANBOULAN et al. $)^{115)}$ なども知られてい る。唾液腺における封入体の報告は少ない上う で，著者の知る限りでは次の 2 編があるだけであ る。すなわち TANDLER et al. (1969) ${ }^{571}$ がヒトの 口唇腺終末細胞で, SHACKLEFORD・WILBORN (1969) ${ }^{60)}$ がウシの頻下腺で報告しているだけであ る。TANDLER et al. は32例の biopsy のうち 16
例に封入体を認めた。大きさは約 $1.0 \mu$ ほどで, 単層の膜に囲まれた球形であり，その染色性はエ オジン好性で, それらのうちあるものは Nile blue sulfate 陽性, PAS 陽性であるが, Feulgen 反応 は陰性であるとしている。SHACKLEFORD・WILBORN はかれらが得たものを nuclear body であ るとしている。

nuclear body が発見され，命名されて以後, WEBER et al. (1963) ${ }^{69)}$ はウシの副腎細胞に括い て, KRISHAN et al. (1964) ${ }^{116)}$ はヒトおよびハム スターの tumor を有する状態の胸腺, 脾臓, リ ンパ節などにおいて, ISHII・MORI(1969) ${ }^{117)}$ は正 常マウスのリンパ節において, BOUTEILLI et al. (1967) $^{118)}$ はヒトの gria tumor, encephalitis, bronchial tumor のもの, ハムスター煩辁の carcinoma など種々の病的細胞において, POPOFF et al. (1968) ${ }^{119)}$ はハムスターの脳において，それ ぞれ報告している。

BOUTEILLI et al. は nuclear body 5 種類に 分け, POPOFF et al. および IsHII・MORI は 3 種 類に分類している。BOUTEILLI et al., POPOFF et al., IsHII・MORI は大きさと形とを組み合せ 下分類している。著者も 3 種類の Type に分類す ることができたが, このものの由来, 機能的意義 などについてはほとんど明らかでないので, 単に その形態的なものを分類の基準とした。Type I は細線維物質またはその構成要素の形状のはっき りしない物質が球状を示すもの（図 3), Type II は細線維が環状を呈し，その中心部に特別な物質 を認め得ないもの(図 4)，Type IIIは Type II の 中心に電子密度の高、顆粒状物質を有するもので ある(図 5 )。

大きさは Type Iが最も小さく, Type IIIが最 も大きい傾向を有するが，Type II，IIIでは種々 の大きさのものがある。これらの nuclear body の出現頻度 はきわめて高く，全例において見ら れ, なかでも Type I が最も多い。Type IIIはき わめて少なく，数個の細胞で見られたのみであ る。この所見は ISHII - MORI, BOUTEILLI et al. の報告と一致する。また TANDLER et al. (1967) ${ }^{57)}$ は核内封入体として最も一般的なものは nuclear 
body であるとしているが，唾液腺では著者の知 るかぎりでは, SHOCKLEFORD・WILBORN の報告 があるのみである。しかし著者の検索した資料で はハムスターを初め諸動物（ニホンザル・ツパイ イヌ, ラット, イエウサギ,アブラコウモリなど） の唾液腺の諸種の細胞においてもこのものは広く 存在するものと思われる (未発表)。

この構造物についての意義および機能について は今までのところでは明らかでないが，その出現 を認めた報告では，病的あるいは正常状態の動 物，正常とみなされた組織，病的あるいは正常細 胞においてなど種々である。

nuclear body の組織化学的研究が光顕的になさ れているが,このものは DNA を含まず(FROELICH et al. 1965) ${ }^{120)}$, PAS 弱陽性, Feulgen 反応陰性 (WEBER et al. 1965) ${ }^{127}$ であるなどの 報告があ る。また IsHII ・ MORI は Type III の中心部に存 在する 電子密度の 高、顆粒は, 酢酸ウラニウム に強く染まり，クエン酸鉛で明るく染まることか ら，それらの染色性と核構成成分の染色性との 比較により，核の顆粒成分または interchromatic granule によく似ており，クロマチンとは異なる としている。

著者も電子染色の点では 同氏らと同じ所見を得 たが，さらに顆粒の大きさ，形からすると CARAMIA et al. (1967) ${ }^{121)}$ がヒトの肝細胞核で示した glycogen body の glycogen 顆粒を思わせるもの をも認めた。nuclear body の線維性成分に関して は, KRISHAN et al. が DNase, RNase では消化 されないが, trypsin 処理で消化されることを認 め，蛋白質からなることを報告している。著者の 場合は唾液腺細胞の nuclear body であるが，そ の線維成分む同氏らの所見と一致するものではな いかと考える。以上のことから nuclear body の Type I は蛋白質からなり, Type II は蛋白質 性の線維成分と核成分としての顆粒成分または interchromatic granule からなり, Type III は蛋 白質性の線維成分と核内顆粒成分または interchromatic granule および glycogen 様物質など から構成されているものと推測されるが，正確な ことは今後の研究にまたなければならない。

\section{J 神経終末}

腺細胞と神経終末との関係については, 光学顕 微鏡的に古くから諸種の動物の喠液腺について多 くの研究がなされているが，電顕的には（I 型)神 経終末が腺細胞に 200 250 ̊̊ の間隙をおいて直 接接するものと，（II 型）基底膜外に終って腺細胞 に直接接しない(間隔 $0.1 \mu$ 以上)のものとが報告 されている。(I 型) については次のような報告 がある。SCOTT・PEASE(1959)"はラットの耳下 腺と舌下腺とでは神経終末が直接細胞に接する が，顎下腺では認められなかったとしている。入 江(1960) ${ }^{37}$ もイヌの顎下腺粘液細胞間に異質的原 形質部分が介在するが，これは神経線維の末端で あろうと述べている。RUTBERG(1961) ${ }^{25)}$ はマウス の耳下腺において，KURTZ(1964) ${ }^{12)}$ はラットの耳 下腺，顎下腺および舌下腺のうち耳下腺だけで， SHACKLEFORD・WILBORN $(1968)^{18)}$ はハムスター および antelope-squirrel の耳下腺で，TANDLER $(1965)^{50)}$ はヒトの說下腺で, WILBORN・SHACKL$\operatorname{EFORD}(1969)^{63)}$ はオポッサムの䪽下腺の粘液細胞 間だけで，TANDLER·Ross $(1969)^{58)}$ はヒトの口唇 腺で，それぞれ（I 型)の神経終末について観察し ている。さらに HARD (1970) ${ }^{201}$ はラットのエブネ ル氏腺で 2 個の終末細胞と筋上皮細胞とに同時に 接する神経終末と導管上皮細胞に 接する像とを認 めたと報告している。加賀山 $(1970)^{122)}$ はサルの䇗 下腺粘液細胞と筋上皮細胞とに接する像を認め, また彼 ${ }^{45}$ はネコの䫟下腺でも同様に粘液細胞と筋 上皮細胞とにのみ直接接する像を 報告している。

一方, PARKS $(1961)^{6)}$ はラット，マウスの耳下 腺で, 藤田ら $(1964)^{41)}$ はイヌ䫛下腺で, GARRETT $(1966)^{44)}$ はネコの大唾液腺で, TAMARIN et al $(1964)^{41)}$ はイヌの顎下腺で, GARRETT $(1967)^{531}$ はヒトの耳下腺 および狉下腺において，それぞれ （II型）は認められるが（Ｉ）型は認めらないと報告 している。

以上のことから大多数の 唾液腺実質細胞に神経 終末の直接接するのが認められるようであるが， しかしその出現頻度は高いものではないようであ る。また終末細胞, 筋上皮細胞への接着がおもで, 峡部と線条部との細胞への接着はほとんど 報告例 
がない。さらに晾下腺では粘液細胞への接着は認 められているが，漿液細胞への接着例は 報告がな く注目に値する。著者のハムスターの耳下腺では 比較的多くの神経終末が終末細胞に 接着する像が 認められる。Kurtz は小葉間結合組織の神経線維 は常に血管に伴うと述べているが，著者の所見も 同じようである。また藤田らによれば，ScoTr・ PEASE および入江は腺細胞または筋上皮細胞と神 経終末との間のシナプス 構造は見いだしていない と記しているが,著者の所見も上述したRUTBERG, KURTZ, SHACKLEFORD-SCHNEYER, TANDLER, TANDLER - ROSS, WILBORN - SHACKLEFORD, HARD など諸種動物における例と同様で, 腺細胞 と神経終末との間にはシナプスとしての特別な構 造を有しないものと推測される。峡部細胞への接 着はごく少なく，1例を得たのみである。

神経支配に関して藤田らはイヌの頒下腺の腺細 胞は直接シナプスによる 神経支配を受けるのでは なく, 神経終末から出された物質が組織液に入 り，hormonal に血管壁および腺細胞を刺激する と考えられるとしている。八ムスターの耳下腺終 末細胞では，直接支配を受ける細胞が比較的多く 存在するということができる。峡部細胞, 線条部 細胞では直接支配は考えられず藤田らの説による 可能性が推測される。

唾液腺に交感神経および 副交感神経が分布する ことは周知のとおりである。神経終末に現われる シナプス小胞は種々の形態をなすものが知られて おり，その中には扁平綀状のものと電子密度の高 い芯を有する cored vesicle と呼ばれる形のもの とがある。前者は抑制シナプスに特有であり，後 者はカテコールアミンを含むアドレナリン作動性 線維の終末に多いとしている (浜1968) ${ }^{106) 。 R I C-~}$ HARDSON (1964) ${ }^{123)}$ はウサギの虹彩の研究によっ て，筋に分布する神経をアドレナリン作動性神経 とコリン作動性神経とに分類した。

これらの所見によれば著者の得た 終末細胞基底 および細胞間における神経終末の例はほとんどコ リン作動性のものであるが, TANDLER・ROSS だ けがヒト口唇腺の腺細胞に RICHARDSON のいう 2 種の型の神経終末が 直接接するのを認めてい
る。なお加賀山と GARRETT は小葉間結合組織中 に分布するこの 2 種の型の 神経終末を認めてい る。著者は小葉間結合組織内の動脈の外膜におけ る神経終末に, 電子密度の高い芯を有する cored vesicle の存在を認めた(図37)。これは RICHARDSON の示すアドレナリン作動性神経と一致す る像なので，交感神経由来の神経終末と考える。 このようにハムスター耳下腺には 交感神経および 副交感神経の分布することが，それぞれの終末の 形態からも確認することができた。さらにこの 2 種の神経の分布は HEIDENHAIN (1878) の二重神 経支配説に一致し，また STORMONT (1928) は交 感神経は粘液細胞に, 副交感神経は漿液細胞に興 奞を伝導するとしているが，ハムスターの所見は これにも一致する。しかし影下腺では前述のよう に粘液細胞に副交感神経の分布することが 報告さ れているので, これについてはさらに今後の研究 にまたなければならない。

\section{$\mathbf{K}$ 血 管}

小葉間結合組織内には多くの 血管が分布し小動 脈，細動脈および毛細血管を区別することができ るが，細静脈と毛細血管との区別を明らかにする ことは困難であった。TAKADA (1969) ${ }^{124}$ はマウス の頻下腺において直径 $15 \sim 40 \mu$ の管腔を有するも のを細静脈として，その内皮細胞も毛細血管のも のと同しく細孔を有すると述べている。著者の観 察でも $15 \mu$ 位の管腔を有する血管で，その内皮細 胞に細孔を有するものが認められたが，毛細血管 か細静脈かは明らかでない。 $40 \mu$ 位の太さの血管 は観察しなかったが, $20 \mu$ 位の太さのもので, 細孔 を有しないものが認められたことからすると，40 $\mu$ 位のものでは細孔を有しないのではないかと推 測され，マウスの頻下腺のものとは異なるように 考えられる。さらに毛細血管については BENNETT et al. (1959) ${ }^{125)}$ が基底膜, 細孔および周囲細 胞の出現形態によって分類しているが，ハムスタ 一の耳下腺に分布するむのは, そのうち小腸など に分布する 形式のものと一致すると考えられる。

\section{結論}

ハムスター(golden hamster)の耳下腺の微細棈 
造について電子顕微鏡的研究を行なった 結果次の 知見を得た。

1）ハムスターの耳下腺は終末部, 峡部, 線条 部と小茟間結合組織とからなる。実質細胞として は終末細胞, 終末部基底明調細胞, 峡部細胞, 峡 部基底明調細胞, 線条部明調細胞, 線条部暗調細 胞, 線条部基底明調細胞さよび筋上皮細胞の 8 種 の細胞が区別される。

2）終末部の分泌顆粓は 形態的に 3 種に区別さ れる。しかしそれらはそれぞれ移行的であり, 電 子密度は一般に低い。

3）峡部細胞の分泌顆粒も形態的には 3 種に区 別されるが，それぞれ終末細胞のものとは異な り, 電子密度が一般に高い。

4）線条部明調細胞の分泌顆粒は小胞状で，内 容は均一であり，電子密度がやや高、。

5）分必顆粒の形成に関しては，終末細胞，峡 部細胞においてはゴルジ装置によって形成される 像が追及できたが，線条部明調細胞では明らかで ない。

6）終末細胞，峡部細胞のゴルジ装置はゴルジ 小胞, ゴルジ空胞 および扁平なゴルジ毫からな り，しばしばゴルジ野を形成するが，線条部明調細 胞のものはゴルジ辁がふくらみ，大きな空胞状を 呈する。

7） 終末細胞，峡部細胞の分泌機構は emiocytosis（黒住のIV型)に属するが，峡部細胞の分泌顆 粒は特異な融解によって細線維状化した 後放出さ れる。

8）線条部明調細胞では 䋐毛様 突起, 分泌顆 粓, 特異な細線維束とアポクリン分泌様乫起との 間に密接な関連性があることが観察され，それら の消長と分泌サイクルとの関係が示唆された。

9）峡部細胞の分泌顆粒の内容物が類結晶化す る過程が追及できた。

10）終末部基底明調細胞で 種々の細胞小器官の 発達段階のものが見られ 終末細胞への分化すると 思われる過程が追及できた。

11）耳下腺内に粘液性終末部の混在する 例に遭 遇した。その細胞は耳下腺の前上方で側頭笳上に 存在する眼窝外涙腺 (exorbital lacrimal gl.) の細
胞にきわめてょく似ており，舌下腺の粘液細胞と は明らかに異なる。

12) 終末細胞と線条部明調細胞とに含をれるト ノフィラメントが，著明な横紋構造を示すのがお のおの 1 例ずつ認められた。

13）実質細胞の核に nuclear body がしばしば 認められ，それらは 3 型に区別することができ た。

14）ライソゾームである dense body が実質細 胞にしばしば認められ, 、終末細胞, 峡部細胞, 線 条部明調細胞に多く出現する。それらはゴルジ装 置由来と思われ，それらの種の形態の分化が追及 できた。

15) ライソゾームの multivesicular body が多 くの実質細胞が多くの実質細胞で認められるが， それらはゴルジ豪とゴルジ小胞とによるものと， 亜鈴状に変形した dense body とゴルジ小胞とに よって形成される二つの型があることが追及でき た。

16）神経終末が終末細胞間あるいは 終末細胞基 底に直接接する像がしばしば認められた。これら はコリン作動性終末であって，アドレナリン作動 性終末は動脈外膜にのみ存在が見られた。

17）神経終末が終末細胞に接する場合, 両者の 間に特別な構造を形成しない。

18）筋上皮細胞は峡部および 終末部にだけ存在 し, 線条部では認められない。

19）峡部と線条部の移行部において，峡部細胞 が線条部明調細胞の小胞状の顆粒を 有するものが 見られ,一方線条部において, 暗調細胞が峡部細 胞に類似の細胞形態を示すものが見られた。

穆を終るに臨み, 御指導と御校閲を賜わりました今井 倭武教授ならびに御支援をいただきました汒田大三助教 授はじ教室の各位, 電顕室の伊藤良吉君に深鲋の意を 表します。あわせて日本大学歯学部解剖学教室, 加藤信 一教授に種々の教示を賜わりましたことを深く感謝いた します。

\section{文献}

1) Junquira, L. C. \& Hirsch, G. C.: Cell secretion; a study of pancreas and salivary glands. Intern. Rev. Cytol., 5 : 323-364, 1956.

2) JACOBY, J. \& SiRLIN, J. L.: An electron 
microscopic study of the rat submaxillary gland during its postnatal salivary gland cells. I. The nucleus of bradysia mycorumfrey (sciaridase) with special reference to the nucleolus. J. Cell Biol., 17 : 153-164, 1963.

3）関正利：ラットにおける唾液腺線条部の電子顕 微鏡的研究. 唾液腺シンポジウム, $1: 49,1959$.

4) Scott, B. L. \& PeAse, D. C.: Electron microscopy of the salivary and lacrimal glands of the rat. Am. J. Anat., $104: 115-161$, 1959.

5) Leeson, C. R. \& Booth, W. G.: Histological histochemical and electron microscopical observations on the post-natal develompment of major sublingual gland of the rat. $J$. Dental Res., 40 : 838-845, 1961.

6) PARKs, H. F. : On the fine structure of the parotid gland of mouse and rat. Am. J. Anat., 108 : 303-329, 1961.

7) 関正利：耳下腺の線条部の超微形態. 唾液腺シ ンポジウム, 3 : 30-31, 1961.

8）藤田訓也：㖽下腺の電子顕微鏡的観察. 唾液腺 シンポジウム, 4 : 23-24, 1962.

9) PARKS, H. F.: Morphological study of the extrusion of secretory materials by the parotid glands of mouse and rat. J. Ultrastuct. Res., 6 : 449-465, 1962.

10) ScotT, B. L. \& PEAse, D. C.: Electron microscopy of induced changes in the salivary gland of rat. International series of monographs on oral biology 3. salivary glands and their secretions (edited by Sreebny \& Meyer), 13-44, Pergamon Press. Oxford. London. Edinbargh. New York. Paris. Frankfurt. 1964.

11）藤田訓也：ラット舌下腺の電子顕微鏡的研究. 日本口腔科学会誌, $12: 228-229,1963$.

12) Kurtz, S. M. : The salivary glands. Electeron microscopic anatomy. (edited by Kurtz), 97-122, Academic Press. New York. London 1964.

13) T.amarin, A. \& Sreebny, L. M. : The rat submaxillary gland. A correlative study by light and electron microscopy. J. Morph., 117, 295-352, 1965.

14) TAMARIN, A.: Myoepithelium of the rat submaxillary gland. J. Ultrastruct. Res., 16, 320-338, 1966.

15）藤田訓也：ラット舌下腺のいわゆる zymogen granules の電子顕微鏡的, 細胞化学的研究. 日 組録, $28: 165-183,1967$.

16) BOGART, B. I. : The fine structural locarization of alkaline and acid phosphatase activity in the rat submandibular gland. J. Histo- chem. Cytochem., 16, 572-581, 1968.

17) Luzzatto, A. C., Provichiani, G. \& RosATI, G. : Rat submaxillary gland. an electron microscope study of the secretory granules of the acinus. J. Ultrastruct. Res., 22 : 185-194, 1968.

18) Shackleford, J. M. \& WilboRn, W. H. : Structural and functional aspects of rodent salivary glands including two desert species. Am. J. Anat., 115 : 279-308, 1968.

19) SHACKLFORD, J. M. \& WILBORN, W. H. : Structural and histochemical diversity in mammalian salivary glands. Ala. J. Med. Sci., 5 : 180-203, 1968.

20) HARD, A. R. : The fine structure of von Ebner's gland of the rat. J. Cell. Biol., 44 : 340-353, 1970.

21) 高野邦雄 : 耳下腺終末部の微細構造. 解剖誌会, $45: 22,1970$.

22) Wilborn, W. H. \& SCHNEYeR, C. A. : Ultrastructural changes of rat parotid glands induced by a diet of liquid metrecal. $Z$. Zell forsch, 103 : 1-11, 1970.

23）立花民子：頡下腺顆粒管形成に関する研究. 歯 科学報, $71: 252-265,1971$.

24）覚道要蔵：マウス顎下腺分泌細胞の分泌顆粒形 成過程に関する電子顕微鏡的研究. 阪市大誌, 9 : 5125-5132, 1960.

25) RUTBERG, U. : Ultrastructure and secretory mechanism of the parotid gland. Acta. Odont. Scandi. 19 (suppl 30) : 1-115, 1961.

26) PARKs, H. F. : Unusal formations of ergastoplasm in parotid acinous cells of mice. $J$. Cell Biol., 14 : 221-234, 1962.

27) CARAmia, F.: Ultrastructure of mouse submaxillary gland. I. Sexual differences. $J$. Ultrastrut. Res., 16 : 505-523, 1966.

28) CARAMIA, F.: Ultrastructure of mouse submaxillary gland II. Effect of castration in male. J. Ultrrstrut. Res., $16: 524-536$, 1966.

29）種村百代：成熟家鬼耳下腺の諸機能相における 電子顕微鏡的観察, 解剖誌, $34: 54,1959$.

30) 種村百代：耳下腺組織の電子顕微鏡的研究. I. 耳下腺組織掑食後 $3 \sim 4$ 時間時), 金沢大医解剖 学教室業績集, $58: 1-12,1959$.

31）種村百代：耳下腺組織の電子顕微鏡的研究. II. 耳下腺組織の実験的研究. 金沢大医解剖学教室 業績集, 58 : 13-30, 1959.

32）野口 勉：耳下腺上皮の吸収機構に関する電子 顕微鏡的研究. 鹿児島大医誌, $19: 691-710,1968$.

33）小野江為則, 橋本正淑, 梅谷恵子, 大塚礼子 : 耳下腺上皮細胞の微細構造について. 電子顕微 鏡, 5 : 111-115, 1957. 
34）浜田 驍: 頻下腺細胞の電子顕微鏡的研究. 日 本口腔科学会誌, $8: 346,1959$.

35）浜田 驍：額下腺 (犬)の電子顕微鏡的研究. 阪 大歯誌, 4 : 906-926, 1959.

36）浜田 驍：犬顎下腺の電子顕微鏡的研究. 唾液 腺シンポジウム, $1: 50,1959$.

37）入江正昭：正常及び pilocarpine 投与イヌにお ける䫟下腺の電子顕微鏡的研究. 唾液腺シンポ ジウム, 2 : 76, 1960.

38）関 正利：唾液腺の電子顕微鏡的研究, 犬の耳 下腺における実験的研究. 唾液腺シンポジウム, 2 : 32-34, 1960.

39）吉村不二夫, 入江正昭 : polocarpine 投与イヌ の顎下腺の電子顕微鏡的研究. 唾液腺シンポジ ウム, 3 : 31-32, 1961.

40) 吉村寿人: 唾液腺の水分塩分分泌機構. 細胞化 学シンポジウム, $13: 329,1963$.

41）藤田尚男, 中上和義, 今井雄介, 山本豊 : 犬顎 下腺の電子顕微鏡的研究. (1) 静止時および副 交感線維短時間刺激時の終末部の微細構造. 解 剖誌, 39 : 269-293, 1964.

42）藤田訓也：猫䫛下腺の電子顕微鏡的観察. 日本 口腔科学会誌, $12: 228,1963$.

43) FujitA, K. : Electron microscopic and histochemical studies on submandibular glands of the cat. J. Osaka Univ. Dent School, 4 : 83-99, 1964.

44) GARRETT, J. R. : The innervation of salivary gland. J. Roy. Microse. Soc., 85 : 135162, 1966.

45）加賀山学 : ネコ䫟下腺終末部の自律神経支配に ついて. 解剖誌, 45 : II 8, 1970.

46) Takahashi, N. : Electron microscopic studies on the ectodermal secretory glands in man. II. The fine structure of the myoepithelium in the human mammary and salivary glands. Bull. Tokyo Med. Dent. Univ., 5 : 177-192, 1958.

47) TANDLER, B.: Ultrastructure of the human submaxillary gland. I. Architecture and histological relationships of the secretory cells. Am. J. Anat., 111 : 287-307, 1962.

48) TANDLER, B.: Ultrastructure of the human submaxillary gland. II. The base of striated duct cells. J. Ultrastruct. Res. $9: 67-75$, 1963.

49) Nakamura, F.: An electron microscopic observation of the human submaxillary gland. J. Electron Microscopy., 14 : 140, 1965.

50) TANDLER, B. : Electron microscopical observations on early sialoliths in a human submaxillary gland. Arch. Oral Biol., 10 : 509-522, 1965.

51) NAKamura, F., TAKenaka, B. \& HaMA,
H. : Electron microscopic observation of the human fetus submaxillary glands. $J$. Electron Mircoscopy., 15 : 55, 1966.

52) Sato, M., Noguchi, T. \& Yokoyama, M. : On the secretory granules of the serous cell in the human submandibular gland. $J$. Electron Microscopy., 15 : 1-14, 1966.

53) GARRETT, J. R. : The innervation of normal human submandibular and parotid salivary glands. Arch. Oral Biol., 12 : 1417-1436, 1967.

54) Goodmann, A. D. \& Stern, I. B. : The embryologic and functional development of the labial salivary glands of man. Proc. 45 th Gen. Meeting. Int. Assoc. Dental Res., 102, 1967.

55) TANDlER, B. : Fine structure of acinar secretory granules in the human submaxillary gland. Anat. Rec. (abstract). $160:$ 438, 1968.

56) Tandler, B., Denning, C. R., Mandle, I. D. \& KUTSHER, A. H. : Ultrastructure of human labial glands. I. Acinar secretory cells. J. Morph., 127 : 383-408, 1969.

57) TANDler, B., Denning, C. R., MANDEl, I. D. \& KUTSCHER, A. H. : Ultrastructure of human labial glands. II. Intranuclear inclusions in the acinar secretory cells. $Z$. Zellforsch., 94 : 555-564, 1969.

58) TANDleR, B. \& Ross, L. L. : Observations of nerve terminals in human labial salivary glands. J. Cell Biol., 42 : 339-343, 1969.

59) Shackleford, J. M. \& WilboRN, W. H. : Ultrastructure of bovine parotid glands. $J$. Morph., 27 : 453-474, 1969.

60) Shackleford, J. M. \& Wilborn, W. H. : Ultrastructural aspects of calf submandibular glands. Am. J. Anat., 127 : 259-280, 1969.

61) TAKANO, K. : An electron microscopic study on the striated duct of some mammalian parotid gland. J. Electron Microscopy. (会), 18 : 206-207, 1969.

62）高野邦雄 : ヒツジ耳下腺の微細構造. 解剖誌 (会), $44: 120-121,1969$.

63) WilboRn, W. H. \& SHACKLEFORD, J. M. : The cytology of submandibular glands of the opposum. J. Morph., 128 : 1-34, 1969.

64) LUFT, J. H. : Improvements in epoxy resin embedding methods. J. Biophy. Biochem. Cytol., 9 : 409-414, 1961.

65) Couter, H. D.: Rapid and improved methods for embedding biological tissues in epon 812 and araldite 502. J. Ultrastuct. Res., 20 : 346-355, 1967.

66) OHKura, T. \& TAKashio, M. : Beiträge 
zur Verbesserung der Elektronenfarbung mit den aus nichtwassirigen Flussigkeiten hergestellen Uranylacetatlösungen. 日組録, 27 : 49-56, 1966.

67) Venable, J. H. \& Coggeshall, R. : A simplified lead citrate stain for use in electron microscopy. J. Cell Biol., 25 : 407-408, 1964.

68) 山元寅男 : Toluidin blne による epoxy resin 包埋切片の光学顕微鏡用染色法について. 解剖 誌, 38 : 124-128, 1963.

69) Weber, A. F. \& Frommes, S. P. : Nuclear bodies ; their prevalance, location and ultrastructure in the calf. Science, $141: 912-913$, 1963.

70) Sotelo, J. R. \& Porter, K.R. : An electron microscope study of the rat ovum. J. Biophys. Biochem. Cytol., $5: 327-342$, 1959.

71) Makita, T., Kiwaki, S. \& ShibanaI, D. : The histological study of the salivary glands of the domestic animals. I. The fine structure of the acinar cells of the horse parotid gland. Bull. Fec. Agr. Yamaguchi Univ., 19 : 984-1014, 1967.

72）黒住一昌，小林靖夫：分泌とゴルジ装置. 細胞 化学シンポジウム, 13 : 309-328, 1963.

73) HAM, A. W. : Histology, 6th ed. 140-143, Lippincott J. B. Co., Philadelphia. Toronto. 1969.

74) Beams, H. W. \& Kessel, R. G. : The Golgi apparatus. Intern. Rev. Cytol., 23 : 209-276, 1968.

75）小川和朗, 斉藤多久馬, 馬屋原宏 : ライソゾー 厶の微細構造一最近の問題点. 細胞, 2(4): 2-13, 1970.

76) DE Duve, C. \& Wattiaux, R. : Functions of lysosomes. Ann. Rev. Phsiol., 28 : 435492, 1966.

77) Farquhar, M \& Palade, G. E. : Junctional complex in various epithelia. J. Cell Biol., 17 : 375-412, 1963.

78) COVELl, W. P. : microscopic study of pancreatic secretion in living animal. Anat. Rec., $40:$ 213-221, 1928. 9) による

79) HiRsch, G. C.: Theory of fields of restitution with special reference to phenomena of secretion. Biol. Revs. Combridge Phil. Soc. 6 : 88-131, 1931. 9) による

80) RiEs, E.: Zur Hisophysiologie des Mäusepankreas nach lebandbeobachtung, Vitalfarbineg und stufenuntersuchung Z. Zellforsch. u. mikroskop. Anat., 22 : 523-585, 1935. 9) による

81) Palade, G. E. : Subcellular Particles, 64,
American Physiological Society, Wachington. D. C., 1959. 9) による

82) 河村洋二郎：唾液分泌機序, 歯学生理学 (市川, 河村, 楢原編), 166-171, 医歯薬出版, 東京, 1967.

83) WoOD, R.L.: Some structural features of the bile canaliculus in calf liver. Anat. Record, 140 : 207-215, 1961.

84）市川 操 : 契歯類唾液腺の組織学的研究 II. 解 剖誌, 36 : 206-221, 1961.

85) BRuni, C. \& PORTER K. R. : The fine structuae of the parenchymal cell of the normal rat liver. Am. J. Pathol., $46: 691-$ 755, 1965.

86) Rosenbluth, J. \& Wissing, S. L. : The distribution of exogenous ferritin in toad spinal ganglia and the mechanism of its uptake by neurons. J. Cell Biol., 23 : 307325, 1964.

87) Killarski, W. \& Jasinski,A.: The formation of multivesicular bodies from the nuclear envelope. J. Cell Biol., 45 : 205-211, 1970.

88) SICHER, H. : Orbans oral histology and embryology, 6 th. ed., 273-274, C. V. Mosby Co., Saint Louis. 1966.

89) Provenza, D. V.: Oral. histology, inheritance and development. 430, Lippincott Co., Philadelphia Montoriol. 1964.

90) Ferner, H. \& GANSler, H. : Elektronenmikroskopische Untersuchungen an der glandula Submandibularis und Parotid des Menschen. Z. Zellforsch., 55 : 148-178, 1961.

91) Straus, W.: Occurrence of phagosomes and phago-lysosomes in different segments of the nephron in relation to the reabsorption, transport, digestion, and extrusion of intervenously injected horseradish peroxidase. $J$. Cell Biol., 21 : 295-308, 1964.

92) RHODIN, J. : Correlation of ultrastructural organization and function in normal and experimental changed proximal convoluted tubule cells of the normal kidney. Thesis Kalolinka Instutet. Stokholm. 1954. 48)による

93) Rhodin, J.: Anatomy of Kidney tubules. Intern. Rev. Cytol., 7 : 485-584, 1958.

94) Pappas, G. D. \& Smelser, G. K. : Am. J. Ophthalmol., $46: 229,1958.48)$ による

95) PEASE, D. C.: Infolded basal plasma membrane found in epithelia noted for their water transport. J. Biophys. Biochem. Cytol., 2(Suppl) : 203，1956. 48) による

96) 山元寅男：吸収細胞，細胞学大系（小川, 小田, 黒住, 杉野編)，107-140, 朝倉書店, 東京, 1971.

97）緒方知三郎：唾液腺条紋部の構造並びにその機 能について. 東京医事新誌，3161，2861，1939. 
98）滝沢延次郎, 橋爪藤光 : 唾液腺（特に耳下腺に おける）線条部の微細構造について. 日病会誌, 46 : 370, 1957.

99) IsHIKAWA, A. : A note on the dark cells of the exocrine pancreas. 日組録, $28: 78-88$, 1967.

100）加藤喜太郎：家畜比較解剖図説上，1版，194, 養賢堂, 東京, 1957.

101）今井倭武, 芝田大三, 㟄田天雄, 須賀康夫, 小 野内徹治：猫唾液腺の組織学的並びに組織化学 的研究. 解剖誌 (会), 45 (付) : 1-5, 1970 .

102) WATARI, N. \& BABA, N. : Several findings on the fine structural alternations of the exocrine pancreas after the administration of some chemicals. J. Electron Microscopy, 17 : 327-341, 1968.

103) FAwCETT, D. W. : An atlas of fine structure. the cell, Sanders W. P. Philadelphia, London. 1966.

104) Hamiton, D., Fawcett, D. W. \& ChriSTENSEN, A. K. : A study of hepatic cell fine structure in the salamander, Batraehoseps attenuatus. I. the structure of the crystalloid inclusion. Z. Zellforsch., $70: 347-$ 363, 1966.

105）柴田 治：マウスの膵臓腺房細胞内の 類結晶 の起源とその微細構造. 信州医誌, $16: 1039$ 1052, 1967.

106）山田英智, 内兽耕二, 渡辺陽之輔編集 : 電子 顕微鏡による細胞組織図譜, 第 $1,3,4,5$ 巻, 医学書院, 東京, 大阪, 1968.

107) KUROSUMI, K. : Electron microscopic analysis of the secretory mechanism. Intern. Rev. Cytol., $11:$ 1-124, 1961.

108）峯田天雄 : ツパイ顎下腺の電子顕微鏡的研究. 歯基礎誌(会), $12: 275-276,1970$.

109) Kurosumi, K., Yamagishi, M. \& SeKine, M. : Mitochondrial deformation and apocrine secretory mechanism in the rabbit submandibular organ as revealed by electron microscopy. Z. Zellforsch., 55 : 297-312, 1961.

110) 武田 進 : 細胞分裂, 細胞学 (妹尾, 高木編), 442, 朝倉書店, 東京, 1965.

111) BRODY, I. : The ultrastructure of the tonofibrils in the keratinization process of normal human skin. J. Ultrastruct. Res., 4 : 264-297, 1960.

112) De The, G., Riviere, M. \& Bernhard, W.: Examen au microscope électronique de la tumeur $\mathrm{VX}_{2}$ du lapin domestique derivée du papillome de shope. Bull. Cancer, 47 :
569-584，1960. 118）による

113) Hinglaris-Guilaud, N., Moricard, R. \& BERNARD, W.: Ultrastructure des cancers pavimenteux invasifs du utérin chez la femme. Bull Cancer, $48: 283-316,1961$. 118)に よる

114）山田英智 : 細胞の構造と機能, 現代生物学 I, 126，岩波書店，東京， 1965 .

115) Granboulan, N., Tournier, P., Wicker, R. \& BERNHARD, W.: An electron microscope study of the development of SV 40 virus. J. Cell Biol., 17 : 423-441.

116) Krishan, A., Uzman, B.G. \& HedleyWhyte, E. T.: Nuclear bodies, a component of cell nuclei in hamster tissues and human tumors. J. Ultrastruct. Res., 19 : 563-572, 1967.

117) IsHII, Y. \& MORI, M. : Ultrastructural development of nuclear bodies in lymphocytic cells of normal mouse lymphnodes. $J$. Electron Microscopy., 18 : 128-135, 1969.

118) Bouteilli, M., Kalifate, S. R. \& DELARVE, J.: Ultrastructural variations of nuclear bodies in human diseases. J. Ultrastruct. Res., 19 : 474-486, 1967.

119) Popoff, N. \& Stewart, S.: The fine structure of nuclear inclusion in the brain of experimental golden hamsters. J. Ultrastruct. Res., 23 : 347-361, 1968.

120) Froelich, J. S. \& Lapham, L. W. : Tissue culture studies of gliomas. I. intranuclear inclusions in glial cells. Am. J. Pathol., 47 : 147-158, 1965.

121) Caramia, F., Gherge, G. F. \& Menghini, G. : A glycogen body in liver nuclei. $J$. Ultrastruct. Res., 19 : 573-585, 1967.

122）加賀山学 : サル䪽下腺終末部の 自律神経支配 に関する電子顕微鏡的研究. 解剖誌(会), 45 : 24, 1970.

123) RICHARDSON, K. C. : The fine structure of the albino rabbit iris with special reference to the identification of adrenagic and choligenergic nerves and nerve endings in its intrinsic muscles. Am. J. Anat., 114 : 173-205, 1964.

124) TAKADA, M.: Fenestrated venules of the large salivary glands. Anat. Rec., 166 : 605610, 1969.

125) BennetT, H. S., Luft, J. H. \& HAMpton J. C. : Morphological classifications of vertebrate blood capillaries. Am. J. Physiol., 196 : 381-390, 1959. 

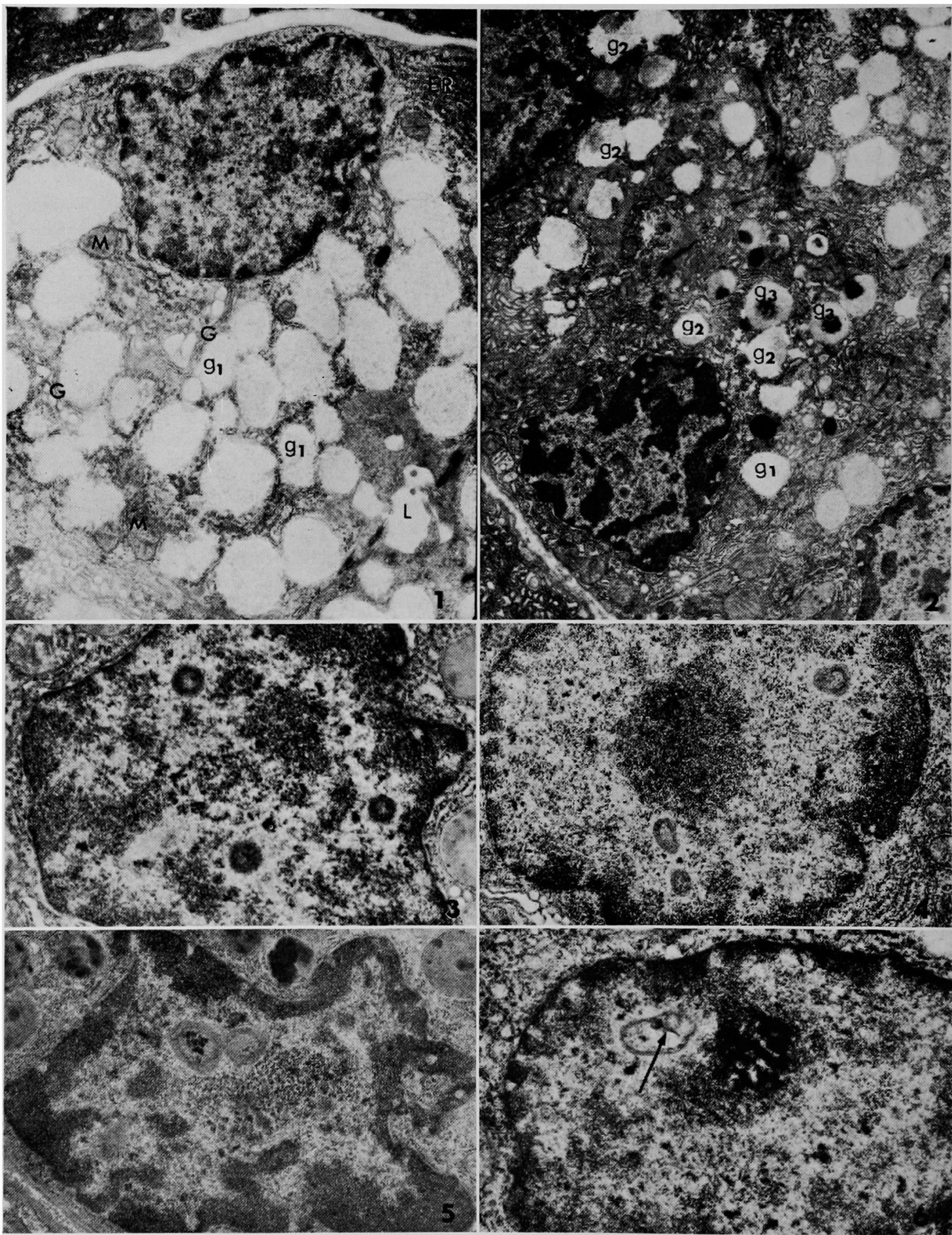

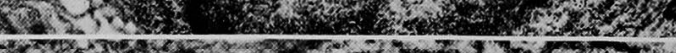

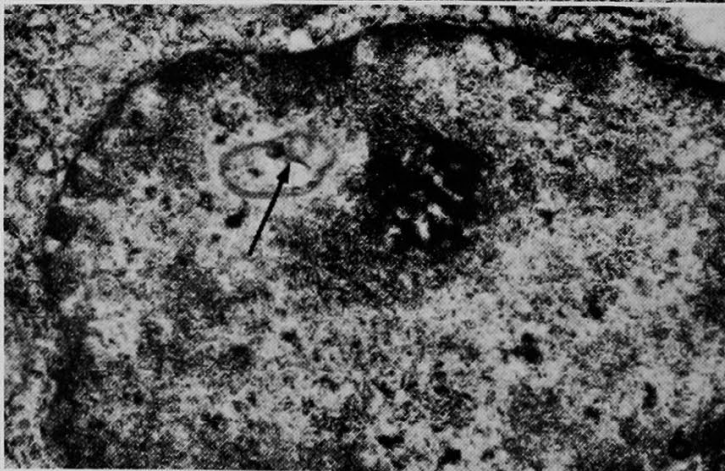




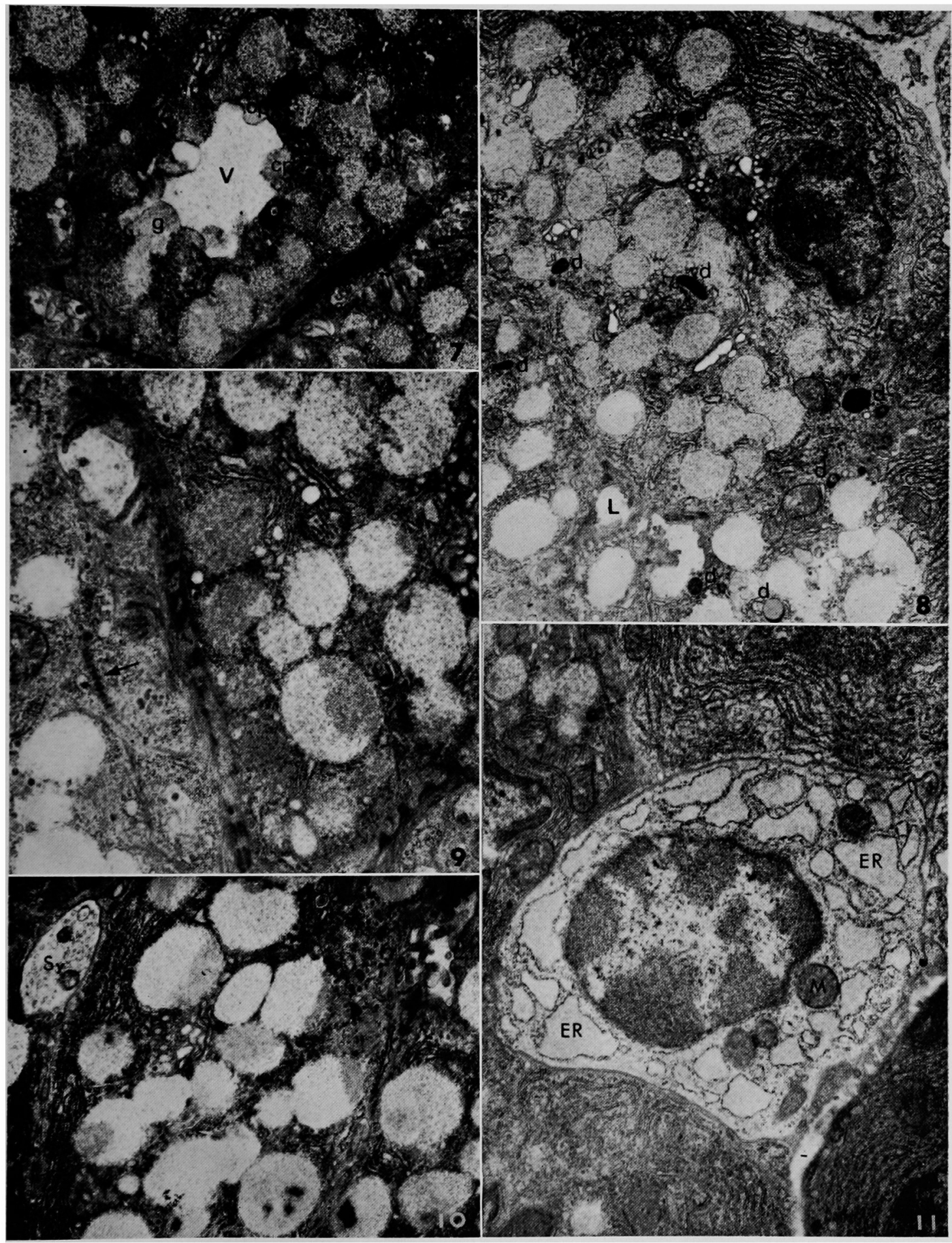


歯基磷誌 $14(1) ： 59-100 ， 1972$.

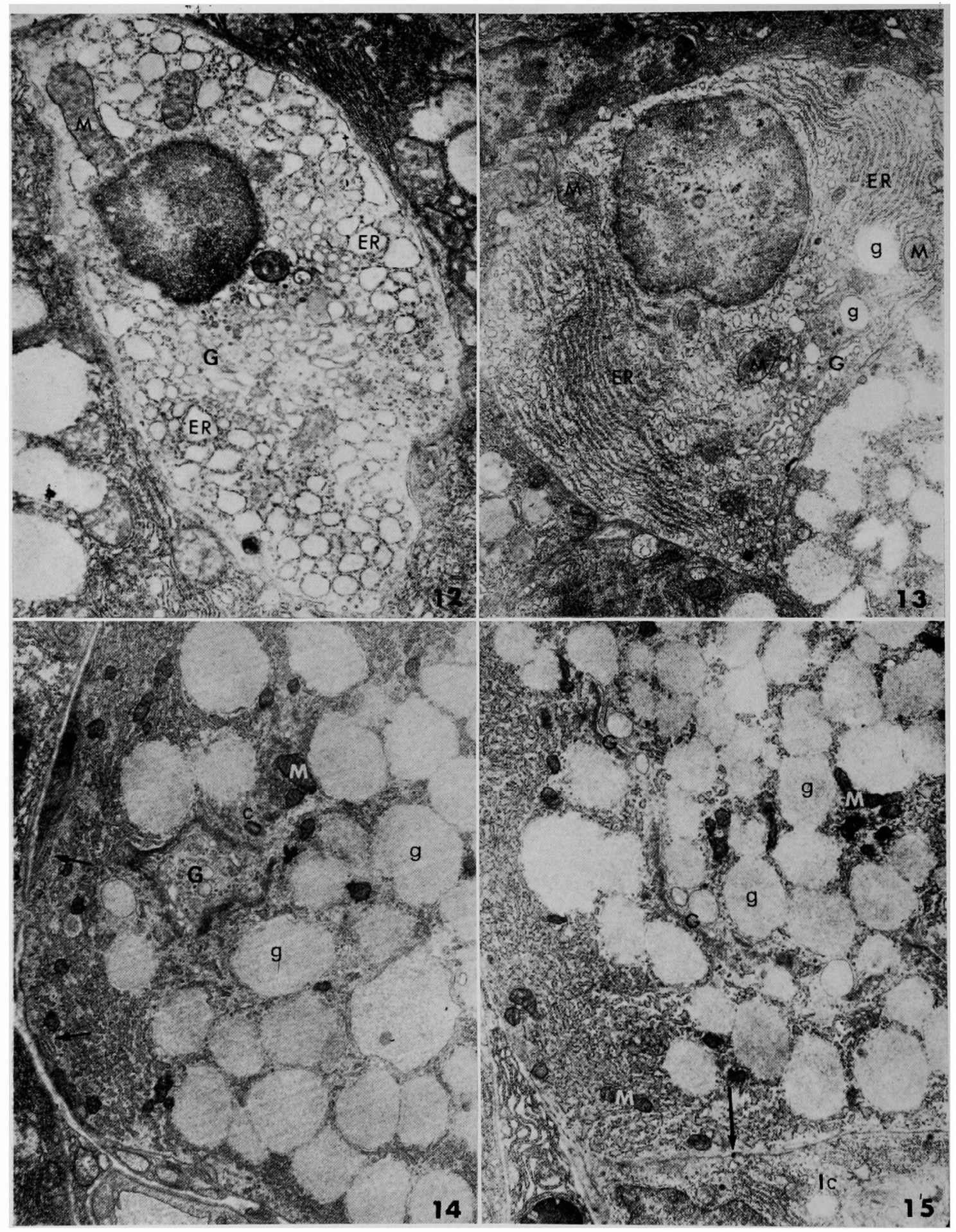




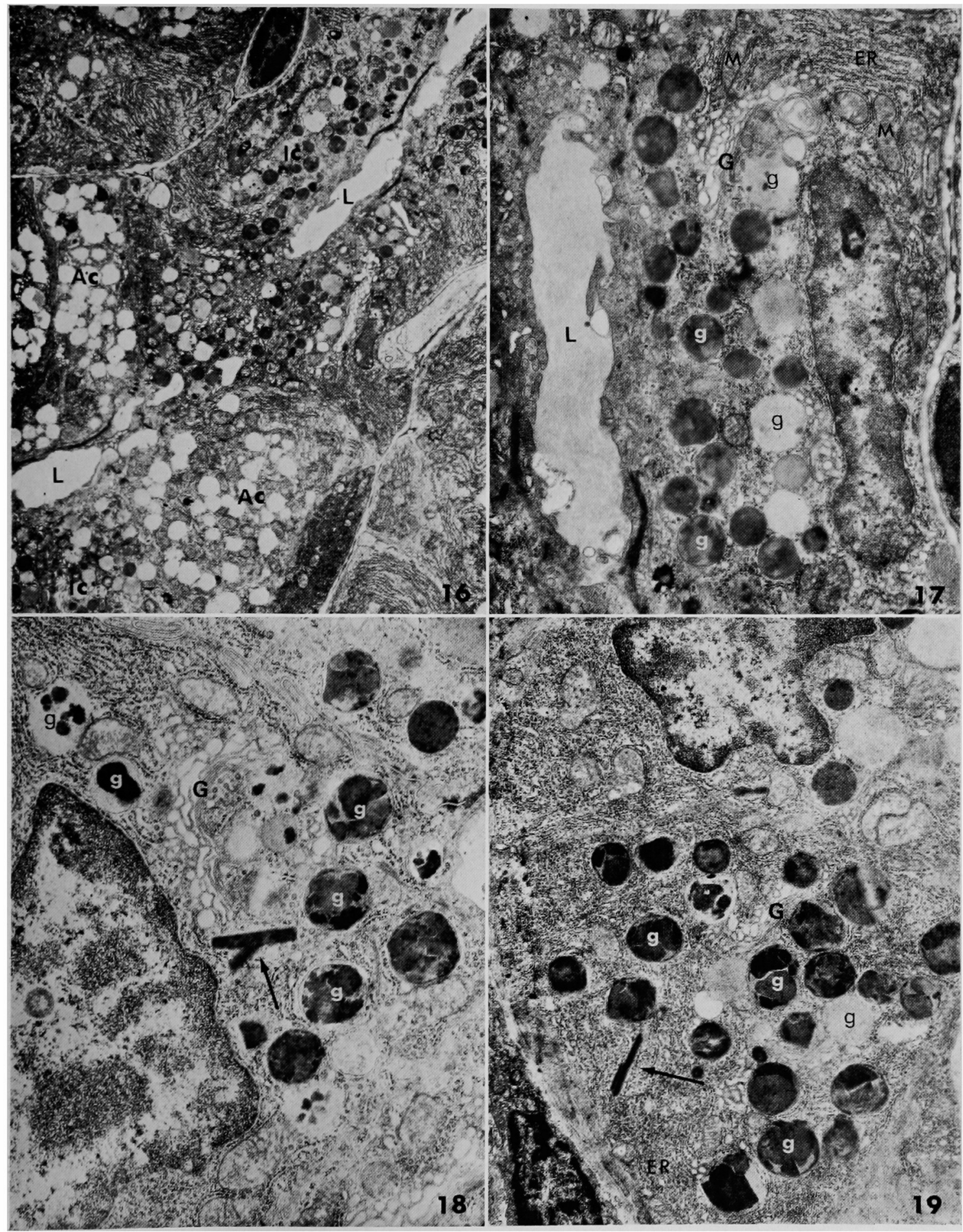




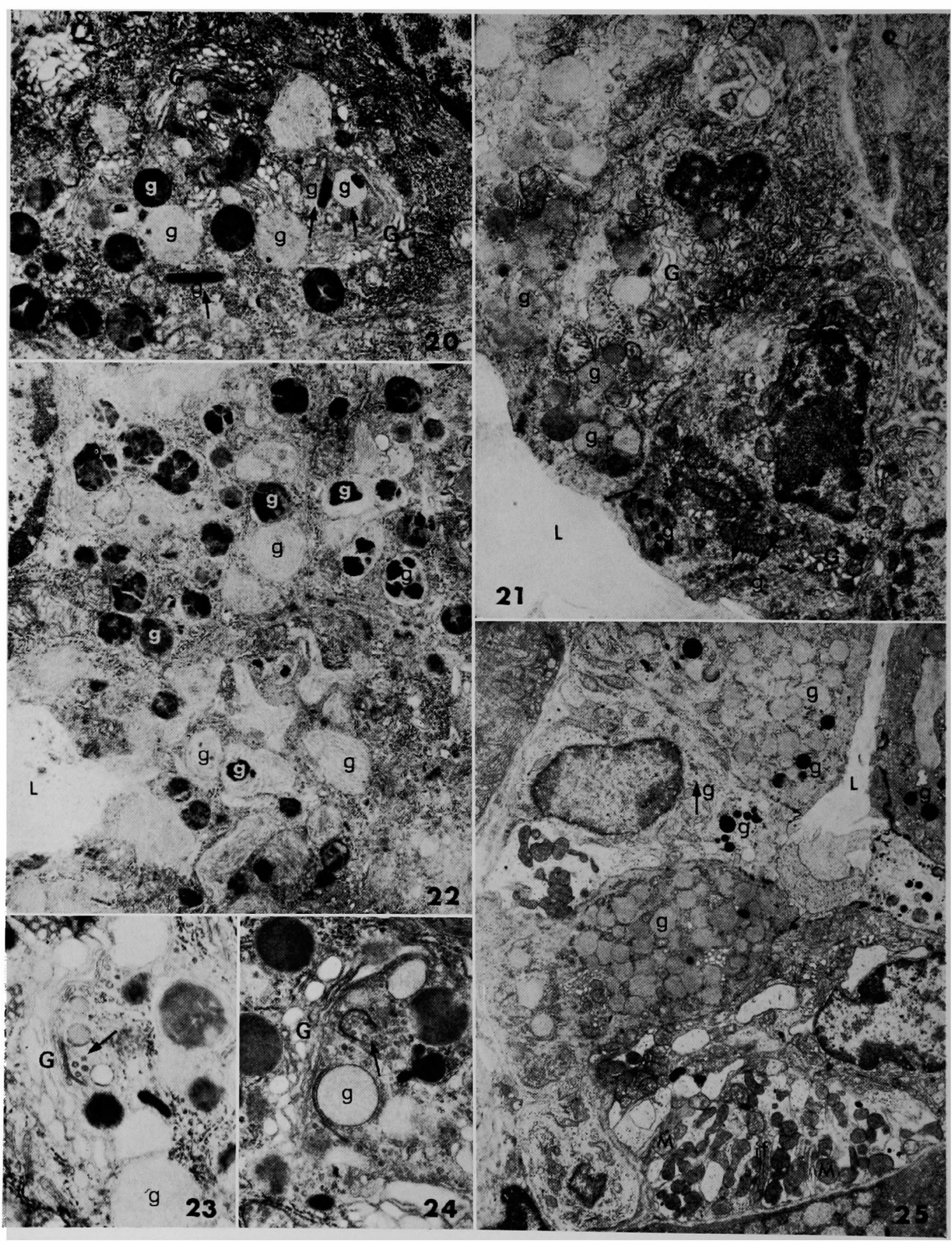



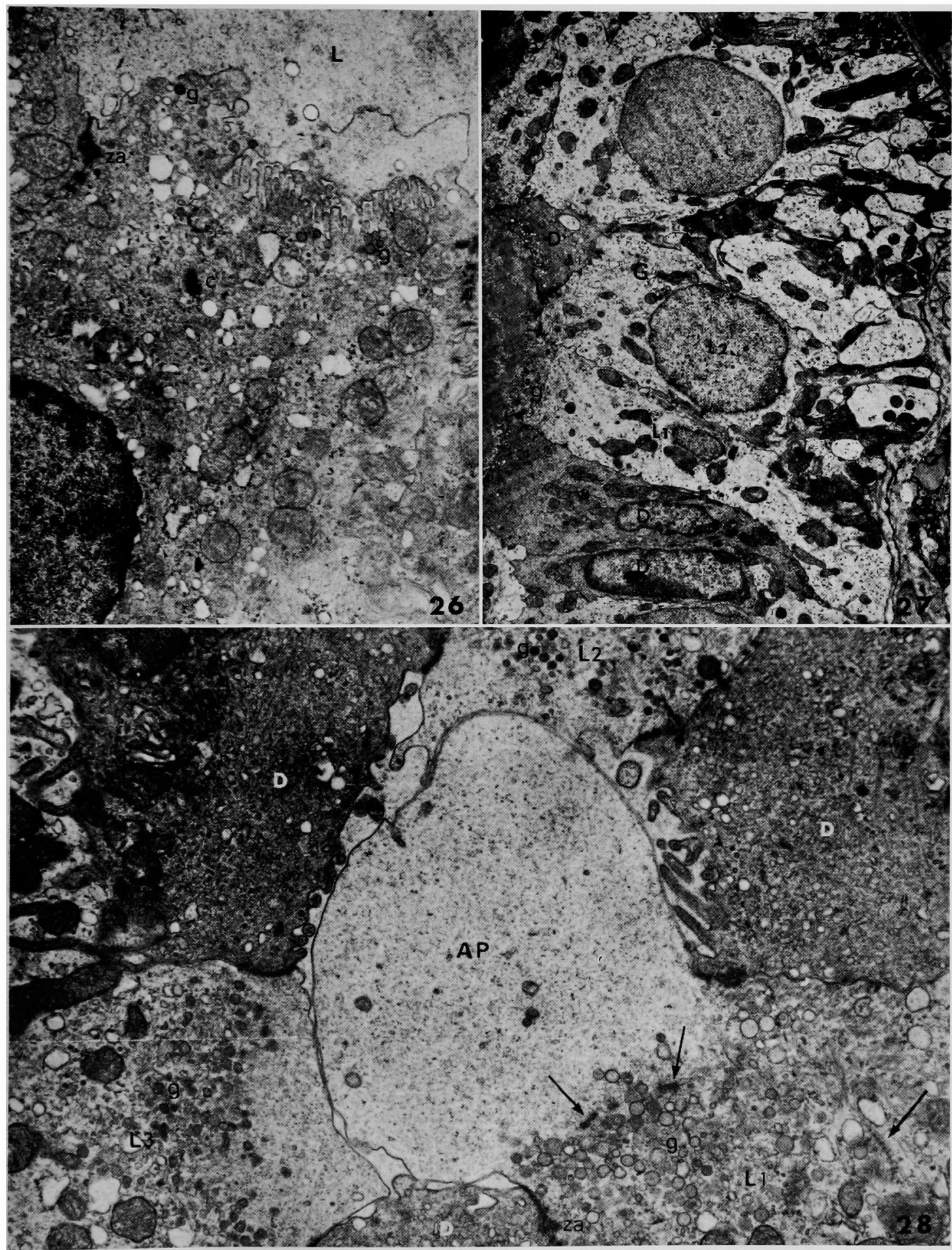
歯基礎誌 14 (1)：59-100，1972.

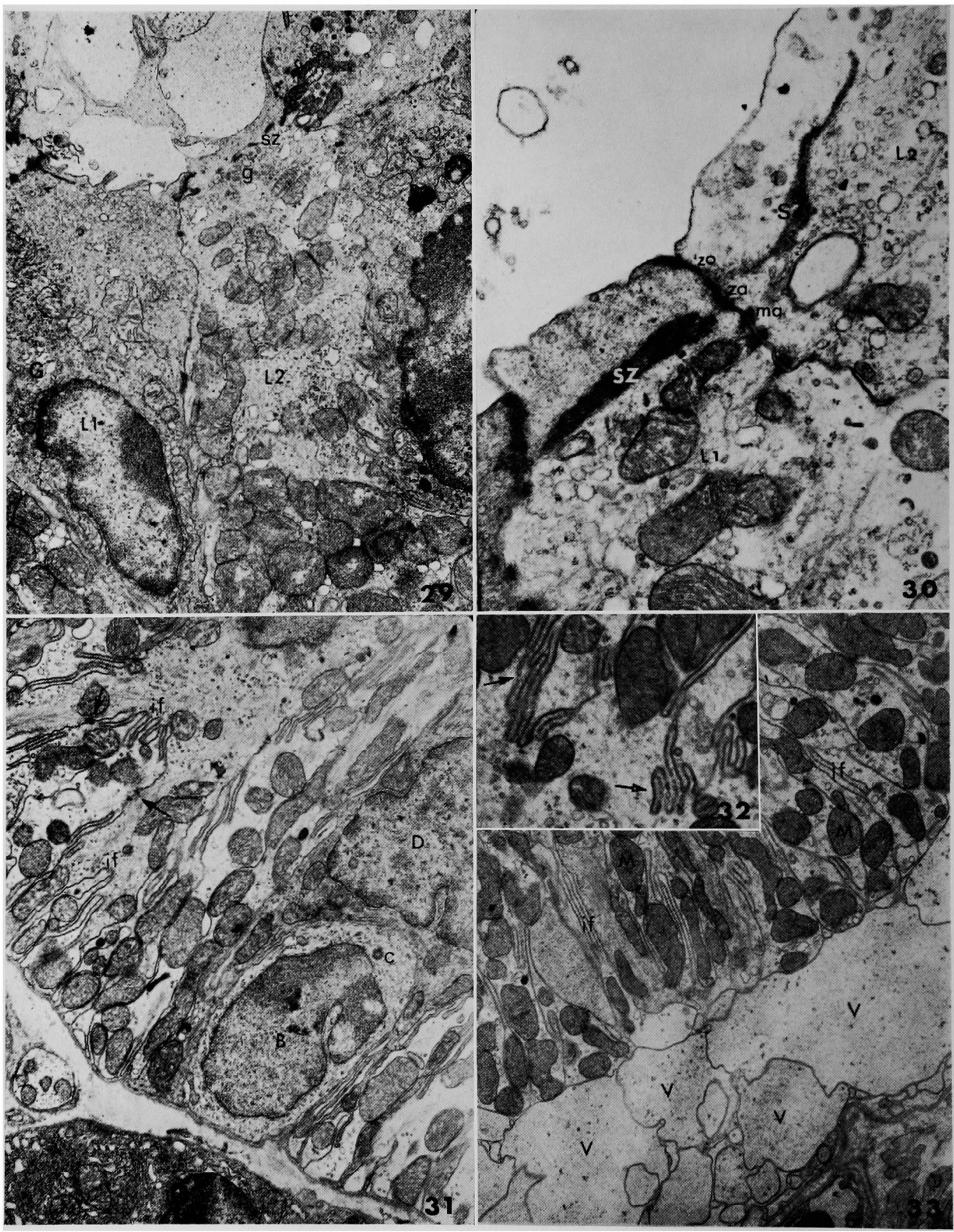




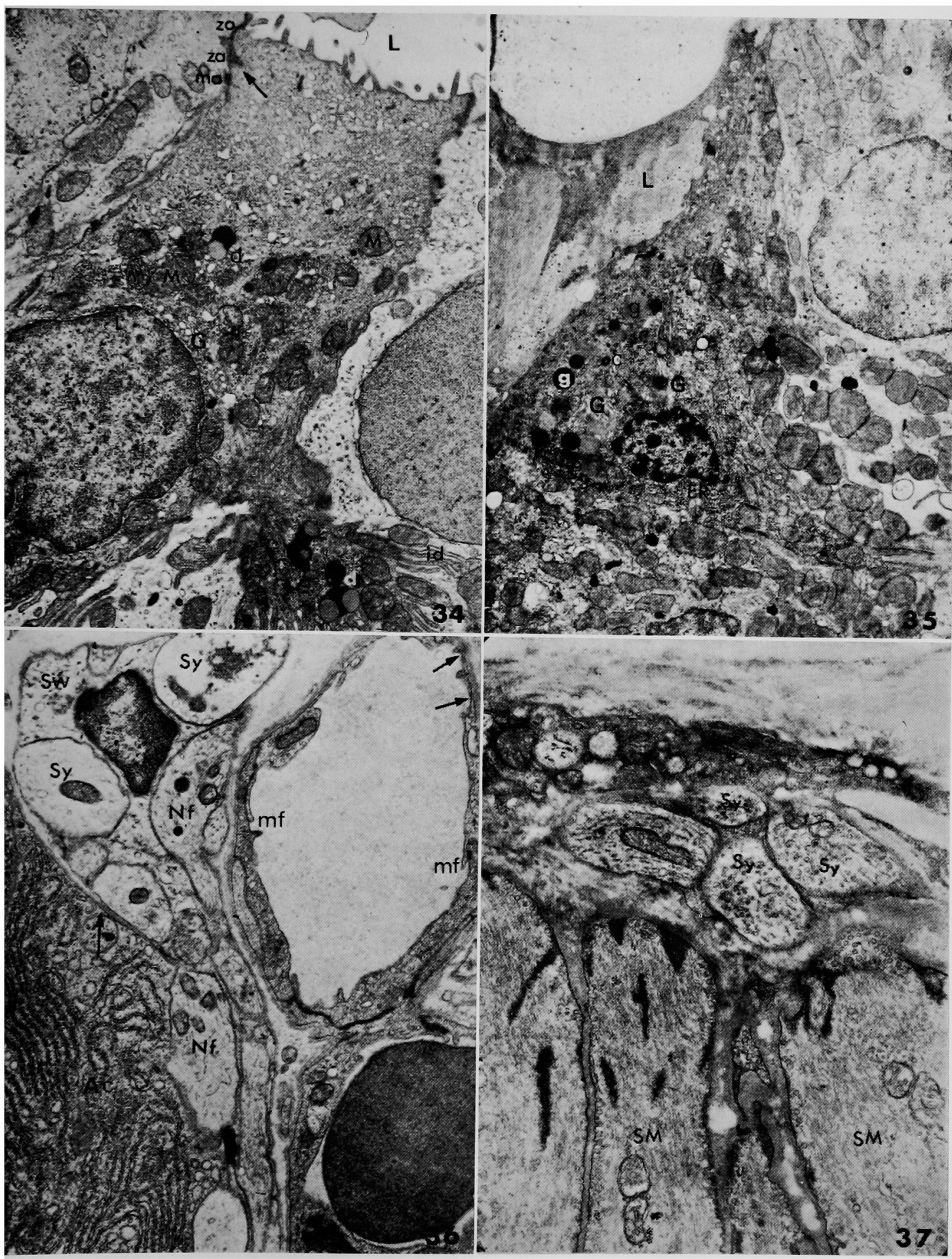




\section{付図の説 明}

図の中の記号は次のものを示す。

$\mathrm{M}$ : 糸粒体, $\mathrm{G}:$ :゙ルジ装置, $\mathrm{E} \mathrm{R}$ : 粗面小胞体, $\mathrm{g}$ : 分泌顆粒, $\mathrm{c}$ : 中心小体, $\mathrm{v}$ : 液胞, $\mathrm{cp}$ : 細胞質, d : dense body, L : 管腔, Sy : 神経終末, if : 基底陥入, zo : zonula occuludens, za : zonula adhaerens (intermediate junction) ma : macula adhaerens(desmosome), id : 嵌合, sz: 細線維束 (separating zone) $\mathrm{mf}$ : marginal fold. $\mathrm{SM}$ : 平滑筋, $\mathrm{Nf}$ : 神経線維

図 1 終末細胞 : 細胞基底に粗面小胞体が層板状を呈し, 核上部にはゴルジ装置, 明るい分泌顆粒 $\left(\mathrm{g}_{1}\right)$ が多 く存在する。それらの間には粗面小胞体，遊離リボゾーム，系粒体が見られる。 $5600 \times 1.2$

図 2 終末細胞 : 分泌顆粒の電子密度が高い芯を有する型 $\left(\mathrm{g}_{3}\right)$, ややそれより電子密度の低い物質を有する 型が $\left(\mathrm{g}_{2}\right)$ 見られる。 $4000 \times 1.2$

図 3 nuclear body：3 個が同時に存在する Type I のもの(峡部細胞)。

図 4 nuclear body: Type IIのものが同時に 3 個存在するもの (峡部細胞)。3100×2.5

図 5 nuclear body: Type IIIももの示す(峡部細胞)。4000 $\times 2.5$

図 6 nuclear body：終末細胞において見られた Type IIのもので，環状をなした線維束の一部が内部に はいり，さらにコイル状(矢印)を呈しながら環状をなす複雑な型のものを示す。 $4000 \times 2.5$

図 7 液胞: 終末細胞の液胞に分泌顆粒が笑入するようなもの, また細胞質の一部が突入するような像を示 す。 $3100 \times 2.5$

図 8 dense body: 一つの終末細胞に種々の形態の dense body が見られ, 矢印のような 環状の dense body が内部に小胞を有する, multivesicular body 様の形態をなすものがある。4000×1.2

図 9 終末細胞で見られた横紋を有する細線維束を示す。 $4000 \times 3$

図 10 終末細胞間に進入した神経終末：内容の均質なシナプス小胞と采粒体があり，副交感神経由来のも の。 $5600 \times 2.5$

図 11 終末部基底明調細胞 : 図11，12，13は終末部基底明調細胞の発達を示す。比較的少ない細胞質内には 大きな液胞状の粗面小胞体, 遊離のリボゾーム, 球状の糸粒体を認める。 $4000 \times 1.5$

図 12 終末部基底明調細胞: 図11より細胞体が大きく, 液胞状の粗面小胞体が小さくなり,一方その増加が 著しい。ゴルジ装置の形成が認められる。 $4000 \times 1.5$

図 13 終末基底明調細胞：ほぼ終末細胞と同様な形態をなし，分泌顆粒の形成が見られる。4000 01.5

図 14 粘液細胞: 終末部に見られた粘液細胞である。分泌顆粒は電子密度が低く大きい。粗面小胞体は小さ い液胞状をなし，内部に比較的電子密度の高い物質を有する。また糸粒体は終末細胞のものより小さ い。細胞基底には基底陥入 (矢印)がある。 $4000 \times 1.2$

図 15 粘液細胞: ゴルジ装置の外方 (凸側)のゴルジ霆内の電子密度が内方のものより高い。矢印は耳下腺の 峡部細胞(Ic) と接着し，明らかにデスモゾームが形成されている。4000×1.2

図 16 終末部と峡部との移行部: 終末細胞 (Ac) が大きく, 電子密度が低く, 峡部細胞 (Ic) は小さくて, 電 子密度が高い。移行部では峡部細胞間に介在するものがあることを示す。 $2100 \times 1.2$

図 17 峡部細胞: 分泌顆粒の電子密度の高いもの, 低いものが区別される。粗面小胞体が基底に層板状を呈 す。ゴルジ装置の外方(凸側)にゴルジ空胞が存在し、ゴルジ露の近くのものは融合して大きくなる。 ゴルジ赦の電子密度が外方から内方になるに従い高くなる。 $5600 \times 1.2$

図 18 類結晶：峡部細胞における「ト」の字形をなす類結晶を示す。核内には nuclear body の Type I の ものが存在する。 $8000 \times 1.2$

図 19 類結晶：峡部細胞の粗面小胞体間に類結晶が見られる。分泌顆粒の内容が亀裂状をなすものが見られ る。 $8000 \times 1.2$

図 20 類結晶形成途上の分泌顆粒を示す。これらの顆粒は模型図 2 の 3 および 4 の段階のものに相当する。 
$3100 \times 2$

図 21 峡部細胞 : 峡部と線条部との移行部に近い細胞であり, 細胞頂部には小胞状の顆粒の集積が認められ る(矢印)。隣接細胞内には峡部細胞の一般的顆粒が存在し，その内には線維状化したものが見られる。 $4000 \times 1.2$

図 22 峡部細胞 : 分泌顆粒の内容が線維状化し管腔に放出される像を示す。各顆粒内容物の線維状化する途 中の種々の形態が認められる。3100×2

図 23 multivesicular dody の形成: 模型図 1 のA-1 に相当し, ゴルジ轵内層のものが屈曲し, そのそばに あるゴルジ小胞を取り曲むような状態を示す(峡部細胞)。

図 24 multivesicular body の形成 : 図23のものよりさらに屈曲しC字形をなす。模型図 1 のA-2 相当する (峡部細胞)。

図 25 峡部と線条部との移行部：基底陥入と多くの系粒体とを有する線条部明調細胞があり，その他のもの は峡部細胞で，2 型が区別される。その一つは分泌顆粒を多く含む細胞で, 分泌顆粒は電子密度の低 い型のものを有する。また線維状化した顆粒内容を有し, 峡部細胞としての特徴を有するものがある。 他の一つは分泌顆粒を多く含まない細胞で, 分泌顆粒として線条部明調細胞の小胞状顆粒に類似のも のを有する (矢印)。 $2100 \times 1.2$

図 26 線条部 : 明調細胞 $\left(\mathrm{L}_{1}, \mathrm{~L}_{2}\right)$, 暗調細胞 $(\mathrm{D})$, 明調細胞は基底陥入を有し, 暗調細胞は細胞基底が基底 膜にまで達しない。明調細胞 $\left(\mathrm{L}_{1}\right)$ は小胞状の顆粒を有するものと，有しないもの $\left(\mathrm{L}_{2}\right)$ とが見られる。

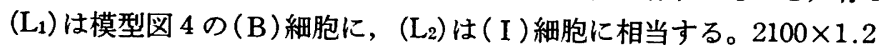

図 27 線条部明調細胞と暗調細胞: ( $\left.\mathrm{L}_{1}\right)$ 細胞の顆粒とアポクリン分泌様突起 (AP) との境界には細線維束の 断片 (矢印)が見られる。また下方に横紋を有する 細線維束を有する (矢印)。( $\mathrm{L}_{1}$ ) 細胞は模型図 4 の (D) 細胞に， $\left(\mathrm{L}_{2}\right) ，\left(\mathrm{~L}_{3}\right)$ は (C) 細胞に相当する。 D : 暗調細胞。 $4000 \times 2$

図 28 線条部明調細胞 : 紱毛様突起を有し, その直下に小胞状顆粒を有する。左上方の頂部には絨毛様突起 が消失し，顆粒がはいり込んでいる。この細胞は模型図 4 の (B) 細胞に相当する。 $3100 \times 2$

図 29 線条部明調細胞 : $\left(\mathrm{L}_{1}\right)$ 細胞の顆粒が細線維束の断片より上方にまだ移動しない状態のもの。 $\left(\mathrm{L}_{1}\right)$ は 模型図 4 の $(\mathrm{G})$ 細胞， $\left(\mathrm{L}_{2}\right)$ は $(\mathrm{A})$ 細胞に相当する。 $3100 \times 1.5$

図 30 線条部明調細胞：( $\left.\mathrm{L}_{1}\right)$ 細胞は発達した細線維束が zonula adhaerens $(\mathrm{za})$ に付着している。 $\left(\mathrm{L}_{2}\right)$ 細胞 の細線維束も長く伸びているが, 消失する過程のもので, 顆粒の数個が細線維束下より頂部に移動し つつある状態を示す。 $\left(\mathrm{L}_{1}\right)$ 細胞は模型図 4 の ( F ) 細胞, $\left(\mathrm{L}_{2}\right)$ 細胞は $(\mathrm{G})$ 細胞に相当する。10000×1.2

図 31 線条部明調細胞と基底明調細胞 : 基底明調細胞(B)の上方には暗調細胞があり，その核内に nuclear body の Type I のものがある。基底明調細胞には中心小体, 糸粒体, 粗面小胞体などが少量見ら れる。この細胞の両側には明調細胞が接し, 陥入膜にデスモゾーム (矢印)が見られ, 一部の細胞質は 隣接細胞のものであることが示される。4000×1.2

図 32 線条部明調細胞 : 基底陥入膜の一部が小胞化し, 連鎖状に配列する(矢印)。 $4000 \times 3$

図 33 線条部明調細胞 : 細胞基底部に液胞状の構造が見られることがあり,その内部にはポリゾーム, 小胞 などが少量認められる。上方には一般に見られる陥入膜と采粒体との配列が見られる。 $4000 \times 1.2$

図 34 線条部暗調細胞 : 細胞全体の電子密度が高い。管腔側隣接面には junctional complex が見られ, zonula adhaerens には細線維束が付着する(矢印)。右下方には指状突起を出して隣接する明調細陶 と嵌合によって接着する。 $4000 \times 1.2$

図 35 線条部暗調細胞 : 粗面小胞体, ゴルジ装置はよく発達し, 分泌顆粒は大きく, 電子密度の高いもの, やや低いものが見られ，峡部細胞によく似る。 $3100 \times 2$

図 36 神経線維の終末細胞への接着と毛細血管 : シュワン氏細胞 $(\mathrm{Sw})$ に神経線維(Nf) と神経終末が接し, それらの線維が終末細胞(Ac)に直接接する。終末細胞を取り囲む基底膜は神経線維のものに連続す る (矢印)。神経終末のシナプス小胞が類結晶様に密に配列するものがある(上方)。毛細血管の内皮細 
胞には pinocytotic vesicles が見られ，細孔(矢印)がある。また内皮細胞間接着部に marginal fold が見られる。内皮細胞の外側には周囲細胞の一部が存在し，その外方に連続した基底膜がある。4000 $\times 1.2$

図 37 小動脈の外膜に存在する神経終末 : 下方には中膜をなす平滑筋, 上方にはコラーゲン線維が見られ, 中央の神経終末の内部には有芯のシナプス小胞, 禾粒体, 神経細線維が見られる。これらの神経終末 は交感神経由来のものである。10000×1.2 